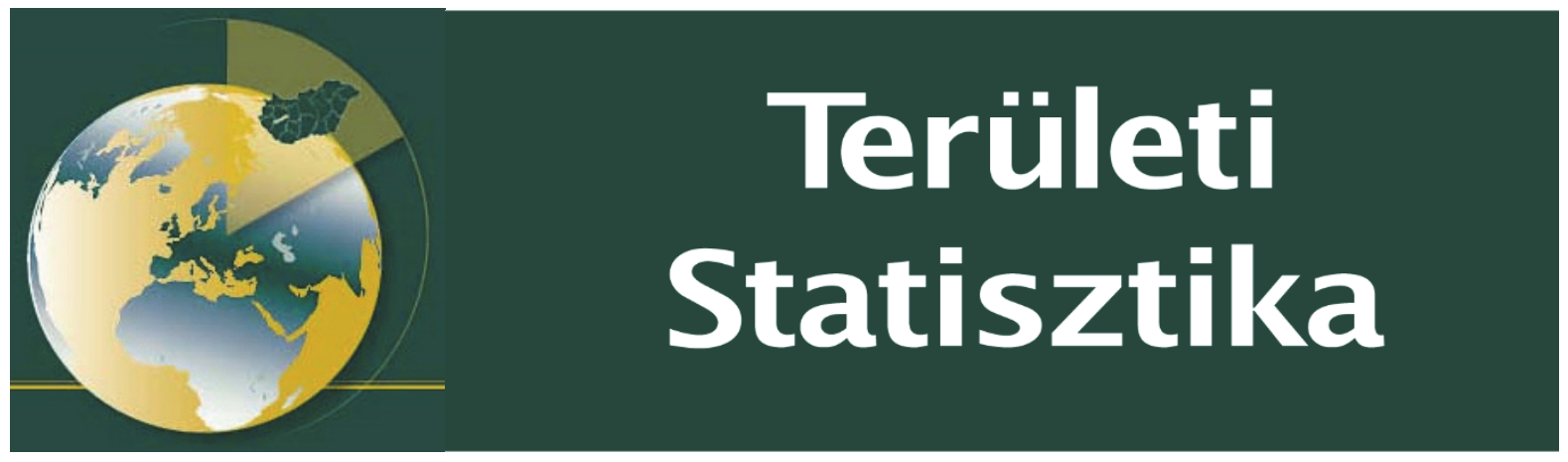

Közzététel: 2019. november 28.

A tanulmány címe:

A városrehabilitáció társadalmi sokszínűségre gyakorolt hatásainak térbeli-társadalmi Szerző: vizsgálata Józsefvárosban

Horváth Dániel, Szegedi Tudományegyetem Gazdaság- és Társadalom-földrajz Tanszék

E-mail: horvathdaniel0207@gmail.com

https://doi.org/10.15196/TS590602

Az alábbi feltételek érvényesek minden, a Központi Statisztikai Hivatal (a továbbiakban: KSH) Területi Statisztika c. folyóiratában (a továbbiakban: Folyóirat) megjelenö tanulmányra. Felhasználó a tanulmány, vagy annak részei felhasználásával egyidejüleg tudomásul veszi a jelen dokumentumban foglalt felhasználási feltételeket, és azokat magára nézve kötelezőnek fogadja el. Tudomásul veszi, hogy a jelen feltételek megszegéséböl eredö valamennyi kárért felelösséggel tartozik.

1) A jogszabályi tartalom kivételével a tanulmányok a szerzői jogról szóló 1999. évi LXXVI. törvény (Szjt.) szerint szerzői műnek minősülnek. A szerzői jog jogosultja a KSH.

2) A KSH földrajzi és időbeli korlátozás nélküli, nem kizárólagos, nem átadható, térítésmentes felhasználási jogot biztosít a Felhasználó részére a tanulmány vonatkozásában.

3) A felhasználási jog keretében a Felhasználó jogosult a tanulmány:

a) oktatási és kutatási célú felhasználására (nyilvánosságra hozatalára és továbbítására a

4. pontban foglalt kivétellel) a Folyóirat és a szerző(k) feltüntetésével;

b) tartalmáról összefoglaló készítésére az írott és az elektronikus médiában a Folyóirat és a szerző(k) feltüntetésével;

c) részletének idézésére - az átvevő mü jellege és célja által indokolt terjedelemben és az eredetihez híven - a forrás, valamint az ott megjelölt szerző(k) megnevezésével.

4) A Felhasználó nem jogosult a tanulmány továbbértékesítésére, haszonszerzési célú felhasználására. Ez a korlátozás nem érinti a tanulmány felhasználásával előállított, de az Szjt. szerint önálló szerzői műnek minősülő mű ilyen célú felhasználását.

5) A tanulmány átdolgozása, újra publikálása tilos.

6) A 3. a)-c.) pontban foglaltak alapján a Folyóiratot és a szerző(ke)t az alábbiak szerint kell feltüntetni:

„Forrás: Területi Statisqtika c. folyóirat 59. évfolyam 6. sqámában megjelent, Horváth Dániel által irt, A városrehabilitáció társadalmi sokszínüségre gyakorolt hatásainak térbeli-társadalmi vizsgálata Józsefvárosban c. tanulmány"

7) A Folyóiratban megjelenő tanulmányok kutatói véleményeket tükröznek, amelyek nem esnek szükségképpen egybe a KSH, vagy a szerzők által képviselt intézmények hivatalos álláspontjával. 


\section{A városrehabilitáció társadalmi sokszínüségre gyakorolt hatásainak térbeli-társadalmi vizsgálata Józsefvárosban}

\section{The socio-spatial analyses of impacts of urban renewal on social diversity within Józsefváros}

Horváth, Dániel A tanulmány a városrehabilitáció rendszerválto-

Szegedi Tudományegyetem Gazdaság- és Társadalomföldrajz Tanszék E-mail: horvathdanie10207@gmail.com

Kulcsszavak: Józsefváros, térbeli-társadalmi vizsgálat, városrehabilitáció, szegregáció, dzsentrifikáció, társadalmi diverzitás, társadalmi kohézió, társadalmi mobilitás, gazdasági teljesítmény zást követô időszakban kifejtett társadalmi hatásainak szerepét vizsgálja a társadalmi sokszínűség (diverzitás) átalakulásában, Józsefváros példáján. A szerző az empirikus kutatás eredményeit egyrészt tágabb földrajzi léptékbe helyezte, másrészt a kvantitatív vizsgálat eredményeit kvalitatív kutatási eredményekkel egészítette ki.

A munkaerôpiaci szegmentáció vizsgálata kimutatta, hogy bár jelentősen emelkedett Józsefváros lakosságának általános státusa, a városnegyedek szintjén az emelkedés nagyon egyenlőtlen volt.

A disszimilaritási index szerint 1990 és 2001 között a kerületben nőtt a térbeli elkülönülés, egyfajta homogenizáció ment végbe Józsefváros társadalmában. A 2000-es évtizedben az index kerületi értékei - szemben a fôvárosi trendekkel csökkentek, ezáltal a helyi társadalom keveredése volt megfigyelhetô.

A vizsgálat megállapította, hogy a városrehabilitáció a dzsentrifikáció és studentifikáció révén erőteljesen hatott a társadalmi sokszínűségre, legkevésbé a társadalmi mobilitásra, leginkább a társadalmi kohézióra és a gazdasági teljesítményre. Általában a városrehabilitáció a kezdeti szakaszában erôsíti egy városrész sokszínűségét, hosszú távon azonban a homogenizáció irányába hat. A városrehabilitáció negatív társadalmi hatásainak ellensúlyozása miatt a beavatkozások szerves részének kell tekinteni a társadalmi, szociális, közösségfejlesztési eszközöket, melyek hozzájárulhatnak a társadalmi sokszínűség megőrzéséhez. 
The paper examines the role of urban renewal following the regime change within transformation of urban diversity in the case of Józsefváros.

The rising of socio-economic status of local society can be detected based on the quantitative investigation in Józsefváros. The study showed that the rise of socio-economic status has been very unequal on the quarter-level.

The increasing spatial segregation between different occupational groups was revealed by dissimilarity analyses at neighbourhood level between 1990 and 2001. Social homogenization took place in this period of time. Later on this trend has turned and the mixing of local society was observed in Józsefváros between 2001 and 2011. These results differ from the outcomes of citywide researches. The heterogeneity of population occurred in Józsefváros, while homogenization was dominant in Budapest.

Józsefváros is seen as a rapidly changing part of Budapest, affected by urban renewal programmes and new waves of higher status people. According to the calculation of segregation index, it could be emphasized that the level of residential segregation in Józsefváros in 2011 was below the values measured in 2001.

Based on this research it can be stated that urban renewal has a strong impact on urban diversity, it has less impact on social mobility, and somewhat more impact on social cohesion (negative) and economic performance (positive).

Keywords: It can be also concluded that it is necessary to Józsefváros, consider the diversification of urban renewal pracsocio-spatial analyses, urban renewal,

segregation, gentrification, social diversity, social cohesion, social mobility, economic performance tices carried out in Józsefváros. The investigations showed that different types of urban renewal interventions have different impacts on urban diversity.

This paper highlighted that social and community improvements, which contribute in particular to preserving urban diversity, should be an integral part of interventions to counteract the negative social effects of urban renewal activities.

Beküldve: 2019. június 5.

Elfogadva: 2019. október 11.

Területi Statisztika, 2019, 59(6): 606-643; DOI: 10.15196/TS590602 


\section{Bevezetés}

A sokszínúség (diverzitás) évezredek óta a városok - különösen a nagyvárosok egyik legfőbb jellemzője (például építészeti, funkcionális, társadalmi, gazdasági értelemben), mégis ennek elemzése csak az utóbbi években került a tudományos érdeklődés homlokterébe. A társadalomföldrajzi kutatásokban a diverzitásvizsgálatok a 2000-es évekig jellemzően etnikai és vallásföldrajzi megközelítésűek voltak, és elsősorban makrotérségi szinten elemezték a folyamatokat. E folyóirat hasábjain is jelentek meg az elmúlt években olyan etnikai és vallásföldrajzi tanulmányok, melyek ezt helyezték a térbeli-társadalmi elemzés középpontjába (Balizs-Bajmóczy 2013, Dövényi-Németh 2014). Ugyanakkor a hazai szakirodalomból hiányoznak azok a dolgozatok, melyek célja a városrehabilitáció és a városi sokszínűség kapcsolatának kimutatása. Tanulmányom a városrehabilitáció társadalmi sokszínűségre gyakorolt hatásainak feltárására vállalkozik.

Európában az elmúlt fél évszázadban gyökeres változáson ment keresztül mind a nagyvárosok társadalma, mind pedig a szervezett városfelújítás. A városi társadalmak átalakulásán belül a meghatározó változások között említhetô a társadalmi-gazdasági polarizáció és a földrajzi mobilitás növekedése, valamint a hozzájuk köthető térbelitársadalmi elkülönülés. Ez idő alatt az intézményesült városmegújitás gyakorlata is jelentôsen átalakult. A nyugat-európai nagyvárosok belvárosi területeinek nagyszabású (jellemzően állam által irányított), infrastrukturális orientáltságú városrekonstrukciós programjai helyett a globális tôke által erősen befolyásolt, a közszféra váltakozó szerepével jellemezhető komplex városrehabilitáció terjedt el (Molotch 1976, Sassen 1991, Smith 2002, 2011).

A kelet-közép-európai nagyvárosok térbeli-társadalmi szerkezete sajátos fejlődési pályát járt be a második világháborút követően. A belvárosok presztízse - az ún. slumosodás nyomán - hanyatlott, a külvárosokban épített lakótelepekre beköltöző fiatal és képzettebb népesség ugyanakkor emelte az övezet státusát (Kovács-Szabó 2017). A szocialista várostervezés homogén egységek (például lakótelepek) kialakítására törekedett, és az egyes funkciók térbeli elhelyezkedését nem a szabadpiaci viszonyok alakították. A rendszerváltozást követően új mechanizmusok jelentek meg a posztszocialista nagyvárosok térszerveződésének alakításában. Sýkora (2009) az új mechanizmusok kettős átalakulását mutatta be, amely magában foglalja egyrészt a posztszocialista gazdaságról a piacgazdaságra és egyben a gazdasági globalizációra való átmenetet, valamint annak hatását a helyi politikai, gazdasági, társadalmi és kulturális viszonyokra.

Kelet-Közép-Európában a szocializmust követően számos kutatás (Leetmaa et al. 2009, Szirmai 2012, Kovács et al. 2013) foglalkozott a szegregáció erősödéséhez vezető folyamatokkal (például szuburbanizáció, demográfiai és életmódbeli változások, zárt közösségek elterjedése, városrehabilitáció). Az említett jelenségek kialakulása és elterjedése a térség nagyvárosaiban gyors ütemben ment végbe, továbbá növelte a társa-

Területi Statisztika, 2019, 59(6): 606-643; DOI: 10.15196/TS590602 
dalmi-gazdasági egyenlőtlenségeket és a lakáskörülmények terén megmutatkozó különbségeket (Marcińczak et al. 2015). Ez a folyamat nemcsak térbeli szegregációként vagy társadalmi polarizációként értelmezhető, hanem térbeli-társadalmi keveredésként is (Sailer-Fliege 1999, Tosics 2009, Smith-Timár 2010).

A posztszocialista nagyvárosok térbeli-társadalmi elkülönülését vizsgáló közelmúltbeli tanulmányok számos esetben kimutatták a szegregáció stagnáló, vagy akár enyhén csökkenő szintjét, valamint a növekvő társadalmi keveredést, ami azonban egy hosszú távú dzsentrifikációs folyamat átmeneti időszakaszaként is értelmezhető (Freeman 2009). E nagyvárosok esetében a növekvő társadalmi keveredéssel valószínűsíthetően hosszabb távon számolni kell. Ezt a feltételezést erősítik a posztszocialista lakótelepekkel kapcsolatos kutatások is (Kährik-Tammaru 2010, Kovács-Herfert 2012, Kovács et al. 2013), melyek azt mutatják, hogy a lakótelepek lakáspiaci helyzete megerősödött, és az új lakosok beáramlása miatt azok társadalmi összetétele sokszínúbbé vált.

A kérdéskör újabb megközelítéseinek egyike Gentile és szerzőtársainak (2012) elméleti keretrendszere, melyben két idealizált várostípus - a homopolisz és a heteropolisz - áll szemben egymással (Berki 2014). A szocializmusban a városok tervezése és épitése során fontos szempont volt a különbségek eltüntetése, ami homogenizációhoz vezetett. A rendszerváltozást követően a térség átalakuló nagyvárosaiban rendkívül gyors ütemú heteropolizáció vette kezdetét. A térbeli-társadalmi szerkezetet tekintve komplex és heterogén városok jöttek létre, melyeket nagyfokú sokszínűség jellemez (Gentile et al. 2012, Egedy et al. 2017).

Nem véletlen, hogy a nagyvárosi társadalmak változásait górcső alá helyező térbeli-társadalmi kutatások elméleti háttere és módszertani eszköztára is jelentősen átalakult. Míg az 1980-as évekig a társadalmi-gazdasági különbségek feltárása és a szegregációs elemzések szerepeltek a nagyvárosokat érintő társadalomföldrajzi érdeklődés középpontjában, addig az 1990-es évektől egyre inkább a társadalmigazdasági felértékelődés, a dzsentrifikáció vizsgálatára helyeződött át a hangsúly. A 2000-es évek végén új társadalomtudományi irányzat bontakozott ki (diverzitáskutatás), amely a sokszínűség különböző formáinak elemzését helyezte előtérbe (Vertovec 2007, Tasan-Kok et al. 2013, Németh 2016).

A kutatási elméletek komplexebb, multidiszciplináris jelleget öltöttek, és általánossá vált az elméletek kontextuális megközelítése. A komplexebb vizsgálatok egyben azt is jelentették, hogy a kortárs elméleti irányzatok a kvantitatív elemzési eszköztárat kvalitatív módszerekkel egészítették ki, ezzel együtt a szociálökológiai szemléletet kontextuális megközelítés váltotta fel. Földrajzi szempontból a makroszintú, strukturális megközelítés felől az elméletek középpontjába a mikroszintű elemzések kerültek, és felértékelődött a hálózatok, kapcsolatok feltárásának szerepe is.

Eközben a térbeli-társadalmi vizsgálatok mellett a hazai városrehabilitáció elmélete és gyakorlata is jelentősen átalakult. Az 1980-as évek városrekonstrukciós beavatkozásaitól a 2000-es évtizedbeli szociális típusú városrehabilitációkig a város-

Területi Statisztika, 2019, 59(6): 606-643; DOI: 10.15196/TS590602 
megújitás egyre összetettebbé vált. A városrészek társadalmi-gazdasági differenciálódásával párhuzamosan a városrehabilitáció is sokszínúbbé vált (van Kempen-Bolt 2009, Tosics 2009, Barrosio et al. 2016). Tanulmányom Józsefváros sokszínűségének változására, ezen belül a városrehabilitációs beavatkozások társadalmi hatásának elemzésére helyezi a hangsúlyt, választ keresve az alábbi főbb kutatási kérdésekre:

- Miként változott Józsefváros társadalmi sokszínúsége a rendszerváltozást követő időszakban, és milyen jellegzetességek mutathatók ki ebben az átalakulásban?

- Milyen módon hatott a városrehabilitáció Józsefváros társadalmi sokszínúségének átalakulására, különösen a társadalmi kohézió, a társadalmi mobilitás és a gazdasági teljesítmény vonatkozásában?

- Miként modellezhető az eltérő városrehabilitációs stratégiák társadalmi hatása?

\section{A társadalmi sokszínưség vizsgálatának elméleti háttere}

A diverzitáskutatás sokrétú, szerteágazó tudományterület. Vertovec (2007) beszámolója szerint a paradigma megszületésében jelentős szerepet játszott az azonos témával foglalkozó, de ahhoz különböző szemléletmóddal közelítő antropológusok, szociológusok, demográfusok, történészek, pszichológusok és geográfusok között egy közös nyelvezet kialakítása iránti igény. E kutatás alapvetôen szociálantropológiai eredetű diszciplína, azonban tudományrendszertani szempontból közel áll hozzá a szociológia és a geográfia is.

A diverzitáskutatás közvetlen tudományos előzményének tekinthető a klasszikus városszociológia, amely tudományterület elméleti megalapozása a hazai szakirodalomban Szelényi Iván (1973) nevéhez fűződik. A dolgozat empirikus része jelentős részben támaszkodik a szociálökológia tudományos eredményeire.

A városok térbeli-társadalmi vizsgálata a tértudományok közül a geográfia, azon belül a városföldrajz fő kutatási területe. A különböző társadalmi és etnikai csoportok együttélésének kérdéséhez a városokkal foglalkozó tudományterületek korábban az elkülönülés, a szegregáció fokának mérésén keresztül közelítettek, később a dzsentrifikáció kutatásában is jelentős szerepet töltöttek be a geográfia képviselői. Korunk tértudományai az elmúlt évtizedekben több paradigmaváltással szembesültek (Kovács-Szabó 2017). Ezek egyike a diverzitáskutatás megjelenése és gyors elterjedése volt (Németh 2016).

A 2000-es évek elején a multikulturalizmus elméletének kritikájaként jelent meg az a társadalomtudományi irányzat, amely túllép azon a megközelítésen, hogy az etnicitás fogalmát használja a társadalmi sokszínûség fő magyarázó tényezőjeként. A különböző társadalmi csoportok együttélésének kérdéséhez a városi társadalommal foglalkozó tudományterületek (például szociológia, geográfia, antropológia) korábban az elkülönülés, kirekesztés vizsgálatán keresztül közelítettek. A globális vándorlás gyorsuló üteme (Lados-Hegedűs 2018) és a nyomában járó növekvő multikultu-

Területi Statisztika, 2019, 59(6): 606-643; DOI: 10.15196/TS590602 
ralizmus kihívásai a kutatók figyelmét szükségszerűen az elkülönülésről a keveredésre irányították (Kovács-Szabó 2017). A társadalmi sokszinníség a legáltalánosabb értelemben a társadalmi elkülönülés módjait, a sokféleség formáit jelenti, mely magában foglalja az emberek közötti különbözőség valamennyi lehetséges dimenzióját, az életkortól, a nemtól kezdve a társadalmi osztályon át az etnikai és vallási hovatartozásig.

Vertovec (2007) megállapítása szerint a diverzitáskutatás mindenekelőtt a társadalmi és a kulturális különbségek észlelésével, konfigurációival, interakcióival, térbeli manifesztálódásával és ezek politikai vonatkozásaival foglalkozik. Lényege, hogy nem az etnikai, nyelvi és vallási csoportok elemzése felól közelít egy adott problematikához, hanem az egyes, elsô ránézésre homogénnek tủnő társadalmi csoportokon belül fellelhető sokszínűség sajátosságait (például viselkedés, életstílus, kapcsolatok) állítja a vizsgálatok középpontjába. Ez a megközelítési mód merőben más, mint a hagyományos etnikai-földrajzi kutatások, vagy a társadalmi kirekesztésről és dzsentrifikációról szóló elméletek szempontrendszerei (Németh 2016).

A diverzitáskutatás korai fázisának a szuperdiverzitás elméletének időszakát tekinthetjük. Ezt a fogalmat Vertovec (2005) egy interjúban használta először, amikor is azt a tényt kívánta hangsúlyozni, hogy a nemzetközi vándorlás erősödik. Az egyre sokszínúbb sokaság által az 1990-es évektől az Egyesült Királyságba irányuló vándorlási folyamatokban és térbeli-társadalmi mintázatokban új tényezők jelentek meg. A szerző szerint a trendek mögött új típusú társadalmi jelenségek és interakciók jöttek létre.

A szuperdiverzitás elméletével szemben számos kritika jelent meg. Makoni (2012) Dél-Afrika példája alapján azt állítja, hogy ennek koncepciója hangsúlyosan a társadalmi romantika érzését hordozza, a sokszínúség nyílt ünnepléseként értelmezhetô, ami az egyenlőség hamis illúzióját kelti, különösen a homogenizálással, az erôszakos idegengyúlölettel fütött társadalmakban. Deumert (2014) kritikai állítása, hogy a szuperdiverzitás fogalom használata egy elméleti zsákutcába vezet, mert végső soron korlátozza a kvantitatív mérés lehetőségét. Czajka és de Haas (2014) rámutattak, hogy míg globálisan a bevándorlók száma nőtt, addig a Föld lakossága nagyobb ütemben gyarapodott, ezáltal a bevándorló népesség aránya csökkent, amely megkérdőjelezi a diverzitáskutatás alapállitását.

A 2010-es években látott napvilágot - a szuperdiverzitás elméletének részben kritikájaként, részben továbbfejlesztéseként - a hiperdiverzitás elmélete (Tasan-Kok et al. 2013). E tudományos koncepció megszületésében annak felismerése játszott szerepet, hogy az európai nagyvárosok társadalmán belül meglévő társadalmigazdasági, szociális és etnikai különbségeken felül is egyre több különbözőség mutatható ki. A „hiper” jelző is arra utal, hogy az egyes jövedelmi, etnikai, demográfiai csoportokon belül jelentős eltérések mutatkoznak életstílus, attitűd és aktivitás tekintetében. Nathan (2011) a városi társadalmak sokszínúbbé válásának okait nem csupán az identitások növekvő számának tulajdonítja, hanem annak is, hogy az egyes identitások komplexebbé és rugalmasabbá váltak.

Területi Statisztika, 2019, 59(6): 606-643; DOI: 10.15196/TS590602 
A trend mögött meghúzódik az egyének azon sajátossága is, hogy manapság az emberek már nem egyetlen, hanem növekvő számú identitással rendelkeznek (például homoszexuális, ázsiai, zsidó vagy fogyatékos). Azonos társadalmi vagy etnikai csoporthoz tartozó emberek eltérő hátterủek iskolázottság, foglalkozás, társadalmi kapcsolatok és más jellemzők tekintetében. Nagyon különböző az egyének napi rutinja, életmódja és térbeli aktivitása is.

A hiperdiverzitás elmélete szerint a városi társadalom olyan dinamikusan változik, hogy számos, korábban használt elméleti koncepció a növekvő sokszínúség jellemzéséhez már nem alkalmazható. Az elmélet középpontjában az az állítás áll, hogy napjaink nagyvárosi társadalmai már a szuperdiverzitás elméleti keretei között nem írhatók le, esetükben már a hiperdiverzifikáció jellemző, melynek koncepcionális vázát a városi kormányzás, a társadalmi kohézió, a társadalmi mobilitás és a gazdasági teljesítmény alkotja (1. ábra). Ebben a koncepcióban a városrehabilitáció a városi kormányzás részének tekinthetô, ami meghatározó szerepet játszik a társadalmi-gazdasági tényezők alakításában.

1. ábra

\section{A hiperdiverzitás-elmélet koncepcionális kerete}

The conceptual framework of the hyper-diversity theory

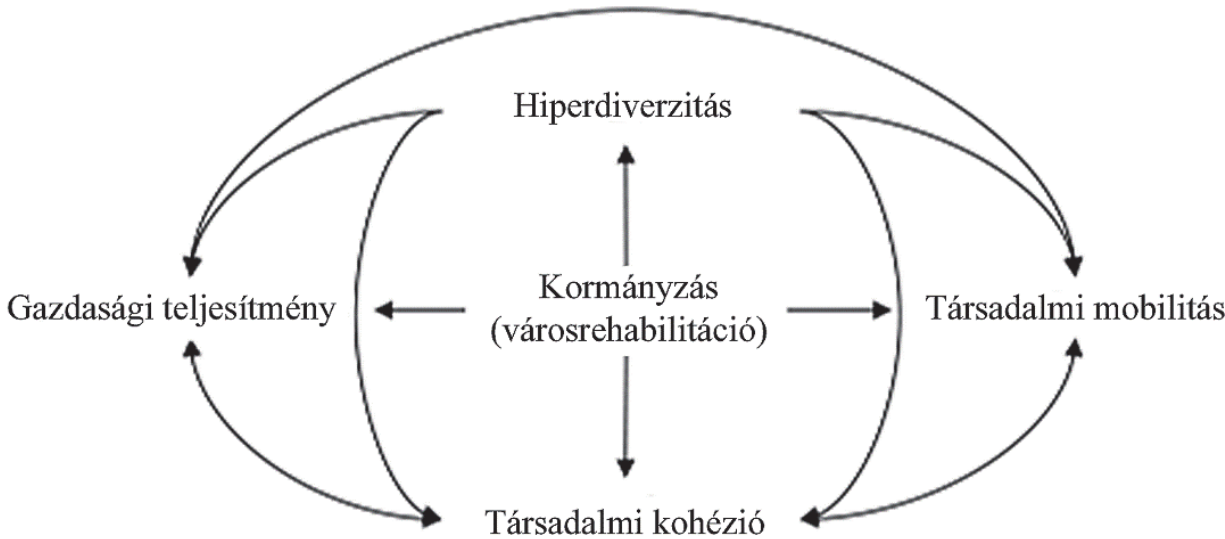

Forrás: Tasan-Kok et al. (2013) nyomán saját szerkesztés.

A társadalmi sokszínűség új formái a szakirodalom szerint sok tényezőből származnak (Sepulveda-Syrett 2007, 2011, Vertovec 2007, Faist 2009). Említett szerzők a legfőbb okokat egyrészt a vándorlás növekedésében és a bevándorlókat kibocsátó országok különbözőségében jelölik meg. Meghatározó jelentőségú az etnikai és a nemzetiségi hovatartozás, a vallási meggyőződés és a nyelvi különbségek köré szerveződő heterogenizálódás. A neoliberalizmus is erôsíti a nagyvárosi társadalmak sokszínűségét és összetettségét (például globalizáció, jövedelmi egyenlőtlenség, szegregáció). Az említett tényezők hatására új társadalmi formációk, hatalmi erők és politikai struktúrák, valamint identitások fejlődtek ki. A városrehabilitáció is egyre 
nyilvánvalóbb szerepet játszott a sokszínűség alakításában, különösen Józsefváros esetében (Boros et al. 2016, Boros-Fabula 2017).

\section{A városrehabilitáció elméleti háttere}

A városrehabilitáció fogalma hazánkban számos tanulmányban, jogszabályban ${ }^{1}$ megjelenik, azonban nincs egy egységesen elfogadott definíciója, ami számos okkal magyarázható. Egyrészt a jelenség másfajta beavatkozásokat takart az elmúlt évtizedekben, másrészt a tevékenység komplex, multidiszciplinális jellegú, emiatt jelentős nehézséget okoz a fogalom egzakt meghatározása.

A városrehabilitáció egyik legkomplexebb meghatározása Egedy-Kovács (2005) tanulmányában jelent meg, mely szerint a városrehabilitáció általában a leromlott állapotú, belső városrészek lakóházainak és lakásainak, közösségi intézményeinek és infrastruktúrájának a felújitása, melynek során arra törekszenek, hogy a városrész jellegzetes szerkezetét, beépítési módját és épületállományának értékes részét megtartsák. Hazánkban alapvetően a városrehabilitációval azonosítunk minden olyan városmegújitási kezdeményezést, amely egy városrész programszerúen végrehajtott megújitását célozza, függetlenül attól, hogy a fogalmat építészeti, városrendezési, szociológiai vagy városföldrajzi értelmezésben használjuk. Jellemzően a városrehabilitációból képzett jelzős szerkezettel jelezzük, hogy valamely altípusról van szó (például szociális, barnamezős, funkcióbővítő).

Európában a belső, elhanyagolt városrészek szervezett megújitásának kialakulása alapvetően a második világháborút követő évtizedre tehető. A központi kormányzatok által szervezett városmegújítás kezdeti idôszaka a városrekonstrukció korszaka volt. Kibontakozásában egyrészt egyszeri hatásként szerepet játszott a második világháborúban elpusztított épületállomány szükséges pótlása, megújítása, másrészt a városmagok idősödő épületállományának múszakilag elkerülhetetlen felújítási igénye. Az újjáépítés eredményeként modernizált városközpontok számos, korábban hiányzó funkciót hordozó épületállománnyal (például bevásárlóközpontok, irodaépületek, szállodák), továbbá jelentősen átalakított köz- és közösségi terekkel (például sétáló övezetek, parkok) gazdagodtak. A városrekonstrukció szinte mindenütt az iparosított építészeti technológiák térnyeréséhez és a lakótelepek elterjedéséhez vezetett (Egedy-Kovács 2005). Ebben az időszakban nem volt lényegi különbség a nyugati és keleti blokk városfelújító gyakorlata között.

1 1993. évi LXXVIII. törvény a lakások, helyiségek bérletére, és az elidegenítésükre vonatkozó egyes szabályokról; 1997. évi LXXVIII. törvény az épített környezet alakításáról és védelméről; 46/1997.(VIII.13.) Fővárosi Közgyűlés rendelete a Fővárosi Városrehabilitációs Keretből juttatható támogatás feltételeiről és a pályázati eljárás rendjéről.

Területi Statisztika, 2019, 59(6): 606-643; DOI: 10.15196/TS590602 
Budapesten az 1970-es évekig a tervezett városépítészeti beavatkozások az ún. buldózeres városrehabilitációból (slum clearance) $)^{2}$ - a leromlott épületállomány nagyobb volumenű lebontásából, új házak építéséből - állt. Akkoriban ezeket városközpont-rekonstrukcióként határozták meg. Házgyári technológiával ekkor építették Budapesten - többek között - a Belső-Óbuda Flórián tér környéki, valamint ÚjpestVárosközpont térségi lakótelepeket. A történelmi belvárosban a városrekonstrukció szélsőséges példájává vált a Józsefvárosban megépített Szigony utcai (újabban Losonci) lakótelep is, a fôvárosban egyetlen kísérletként arra, hogy a belvárost panelházakkal, lakótelepszerű beépítéssel alakítsák át.

A mai értelemben vett városrehabilitáció első kísérletei a városrevitalizáció korszakát jelentették Nyugat-Európában, amelynek gyakorlata az 1970-es években bontakozott ki, és kifejezetten a világháborúk elôtt épült épületállomány felújitásával, valamint helyi kezdeményezések megjelenésével volt jellemezhető. Előzménye, hogy Nyugat-Európában az 1960-as évekre megnőtt az elégedetlenség a slumok felszámolásának módjával és a városszéli lakótelepekkel szemben. Továbbá a belvárosi városnegyedeket kedvezőtlenül érintette, hogy a városok fejlődése és a városfejlesztés súlypontja is a szuburbán területekre tolódott át. Az említett tényezők ráirányították a figyelmet arra, hogy a városok fennmaradását csak a spontán slumosodási folyamatba való központi, hatósági beavatkozás révén lehet segíteni (Csanádi et al. 2010).

A nyugat-európai és a posztszocialista típusú városmegújitás jellegében, céljaiban és tartalmában az 1960-as éveket követően vált el élesen egymástól, és ez a különbség alapvetően a rendszerváltozás időszakáig fennmaradt. A városmegújítás NyugatEurópában az 1970-es évektől, hazánkban és a posztszocialista nagyvárosokban csak az 1990-es évektől kezdte (újra)felfedezni a belvárosi negyedeket (Egedy-Kovács 2005). Ezzel egy időben fokozatosan erősödött az urbanisztika interdiszciplináris jellege. Egyre több tudományág, különösen a társadalom- és viselkedéstudományok jelentek meg a városokról való gondolkodásban, a maguk sajátos szemléletével, fogalmaival (Csanádi et al. 2010).

A budapesti várospolitikában a mai értelemben vett városrehabilitáció fogalma első ízben 1974-ben jelent meg (Lichtenberger et al. 1995), a Belső-Erzsébetváros és Terézváros elavult tömbjeinek felújításos átépítésére tett javaslatban. A szakzsargon ekkortól azonosítja a rehabilitációt a tömbrehabilitációval, ami a KözépsőFerencvárost érintő rehabilitáció hatására a 2000-es évekig meg is maradt.

Nyugat-Európában az 1970-es évek után a városrevitalizációs beavatkozások helyét egyre inkább a városfelíjitás vette át, amelynek legjelentősebb újdonsága az volt, hogy elkezdődött az együttmúködés a városmúködtetés korábban teljesen különálló gazdasági, szociális és múszaki alrendszerei között (Egedy-Kovács 2005). A városmegújítás komplex jellege ekkor kezdett kibontakozni.

2 A ,slum clearence” fogalmát az Egyesült Királyságban 1930-ban elfogadott Lakásügyi törvény (Housing Act) vezette be.

Területi Statisztika, 2019, 59(6): 606-643; DOI: 10.15196/TS590602 
Alapvető változásokat hoztak az együttmúködés és a finanszírozás kérdéskörében az 1980-as évek (Turok 1987). A várospolitika fokozatosan eltávolodott attól a felfogástól, hogy minden szükséges forrást a központi állam biztosít, és helyébe a partnerség szerepének felismerése lépett (Egedy-Kovács 2005). A jóléti államok leépülése volt az egyik leglényegesebb hatása az 1970-es évek gazdasági paradigmaváltásának. A sorozatos válságot kísérő recesszió következtében megerősödött a helyi, különösen a városi szint szerepe, és megnőtt a külső források bevonásának szükségessége. Ezzel egy időben a neoliberalizmus felváltotta az addig uralkodó, a jótékony és erős állami szerepvállalásra épülő keynesianizmust (Szamuely 2004).

Az állam a közösségi gondoskodást egyre nehezebben tudta fenntartani, és az 1990-es években megkezdte a kivonulását a városmegújítási folyamatokból is. A városfenntartás és -fejlesztés felelősségét egyre inkább megosztották a közösségek (önkormányzatok-állam) a piaci és a lakossági szereplőkkel, a városi kis közösségek egyre több közvetlen felelősséget kaptak (Alföldi 2007).

Budapesten a mai értelemben vett modern városrehabilitációs politika alapjait Budapest Főváros Önkormányzata 1994 és 1997 között fektette le. 1994-ben született meg a főváros ez irányú programja, amely koncepcionálisan új alapokra helyezte a Budapesten zajló városrehabilitációt. Az 1997-ben elfogadott Városrehabilitációs Program és az ahhoz kapcsolódó fővárosi önkormányzati rendelet alapvetően a támogatási rendszer múködését, a Fôvárosi Önkormányzat, a kerületi önkormányzatok és a társasházak közötti együttmúködés kereteit határozta meg, valamint szabályozta a Fővárosi Városrehabilitációs Keretből juttatható támogatások rendjét is (Horváth et al. 2018).

Budapesten az 1990-es évektől kibontakozó városrehabilitációs gyakorlatot elsősorban az ingatlanpiaci alapú beavatkozások határozták meg. Ebbe a kategóriába sorolhatók a VI. és a VII. kerület kevésbé koordinált fejlesztései, a középsőferencvárosi tömbrehabilitáció, valamint Józsefváros egyes fejlesztései (például Futó utca rehabilitációja). Budapesten az 1990 és 2010 közötti időszak projektjeit jellemzően a közösségi és magántársulások (Public Private Partnership - PPP), azaz a közszféra és a magánszféra együttmúködései jellemezték, ugyanakkor - a nyugateurópai gyakorlattól eltérően - Budapesten a városrehabilitáció csak néhány esetben valósult meg erre a célra létrehozott városfejlesztő társaságok által (például SEMIX, Rév8 Zrt.).

Nyugat-Európában a gyökeres politikai, társadalmi-gazdasági átalakulási folyamatok vezettek el oda, hogy a városfejlesztés területén az 1990-es években még csak kísérleti jelleggel, de a 2000-es évektől már egyre szélesebb körben jelentek meg a városregenerációs programok. A városregeneráció lényegében olyan átfogó, integrált szemléletmód és beavatkozás, amelynek célja a városi problémák megoldása, továbbá a fejlesztendő terület gazdasági, fizikai, társadalmi és környezeti feltételeinek tartós javítása (Roberts-Sykes 2000).

Területi Statisztika, 2019, 59(6): 606-643; DOI: 10.15196/TS590602 
A hazai gyakorlatban a nyugat-európai értelemben vett városregenerációval nem találkozhatunk, azonban a Budapesten megvalósított beavatkozások közül ahhoz legközelebb az integrált szociális városrehabilitációs programok állnak. Az integrált programokat alapvetően az EU-s támogatások hozzáférhetősége kényszerítette ki, a szociális rehabilitációs programok mellett ún. funkcióbővítő városrehabilitációs programok formájában. Ennek ellenére az első kísérleti jellegú modellprogramok még a Fôvárosi Önkormányzat támogatásával 2005-ben indultak a külsőferencvárosi Illatos út menti tömb, a Kőbánya középső részén fekvő Bihari út menti tömb, valamint a középső-józsefvárosi Magdolna negyed ${ }^{3}$ területén. A józsefvárosi program keretében 2005 és 2009 között sikeresen valósítottak meg szociális és közösségi programokat, foglalkoztatási elemeket, közterület-rehabilitációt és az önkormányzati tulajdonban lévő lakóépületek felújitását magában foglaló városrehabilitációt, melyet a Magdolna Negyed Program formájában még további ütemek (2008-2012, 2012-2016, 2018-) követtek.

A városrehabilitáció elméleti hátterének áttekintése rámutatott arra, hogy Józsefvárosban a hazai városrehabilitáció valamennyi korszakához köthetô egy-egy emblematikus városrehabilitációs beavatkozás (például a Szigony utcai lakótelep megépítése, a Futó utca rehabilitációja, a Corvin Sétány Program, a Magdolna negyed szociális városrehabilitációja), ezáltal a kerület Budapesten egyedülálló lehetőséget kínál a városrehabilitáció eltérő hatásainak vizsgálatára.

\section{Budapest térbeli-társadalmi viszonyainak változása}

Budapest térbeli-társadalmi viszonyainak feltárására irányuló módszeres vizsgálatok közül elsőként Beynon (1943) szociálökológia indíttatású tanulmánya emelhető ki, amely átfogóan jellemezte a két világháború közötti Budapest társadalmi-gazdasági különbségeit, városszerkezetét és funkcionális tagolódását. A szerző kimutatta a különböző társadalmi csoportok viszonylag erős keveredését, amit a századfordulót megelőző bérházas beépítéssel magyarázott. Emellett felhívta a figyelmet a Buda és Pest között mutatkozó markáns térbeli-társadalmi, morfológiai különbségekre. A fővárosra vonatkozó matematikai-statisztikai alapokon nyugvó szegregációs elemzések Probáld (1975) tanulmányáig nyúlnak vissza.

Probáld (1975) kimutatta a szegregáció gyengülését az államszocializmus első évtizedében (1949-1960), majd némi erősödését a rákövetkező évtized (1960-1970) során. Vizsgálataival a Buda és Pest között meglévő társadalmi különbségek is számszerűsíthetôvé váltak. Csanádi és Ladányi (1987) nevéhez kötődik az egyik első részletes, hosszabb időtávot átfogó szegregációs elemzés, mely Budapest térbelitársadalmi szerkezetének 1930 és 1980 közötti változásait mutatta be. Nem utolsó sorban a viharos társadalmi-gazdasági átalakulás megértését is célozva a rendszervál-

\footnotetext{
${ }^{3}$ A városrészek neveit a 94/2012. (XII. 27.) Fôv. Kgy. rendelet 3. melléklete szerint szerepeltetjük.
}

Területi Statisztika, 2019, 59(6): 606-643; DOI: 10.15196/TS590602 
tozást követô években jelentősen megszaporodtak a Budapestet érintő olyan térbelitársadalmi elemzések (Hegedüs-Tosics 1991, Beluszky 1992, Lichtenberger et al. 1994), melyek elsősorban a fővároson belüli térbeli elkülönülés (szegregáció) feltárására összpontosítottak. A kutatások emelkedő száma jelentős részben a Sýkora és Bouzarovski (2012) által feltárt sajátos jellemzőkkel magyarázhatók (például a változatos lakásállomány, a társadalom sokoldalú szegregációs mintázata).

Barta és szerzőtársai (2006), valamint Földi-Van Weesep (2007) arra a kérdésre kerestek választ, hogy melyek voltak a gazdasági szerkezetváltás és a globalizáció következményei, mások az ingatlanpiac átalakulását és annak az épített környezetre gyakorolt hatását elemezték (Hegedüs-Tosics 1994, Kovács-Wiessner 1999, Tosics 2005). További szerzők a lakóhelyi mobilitás - beleértve a szuburbanizációt is - új hullámaira helyezték a hangsúlyt (Beluszky-Timár 1992, Kok-Kovács 1999, TimárVáradi 2001, Csanádi-Csizmady 2002, Konecka-Szydłowska et al. 2018), valamint a társadalmi szegregáció új mintázatának kialakulását helyezték elemzésük homlokterébe (Ladányi 2002, Tosics 2006, Kovács 2012). A Budapestről szóló kutatásokban jellemző hangsúlyeltolódás figyelhető meg a társadalmi-gazdasági, politikai átmenet időszakában. Egyrészt a 2000-es évek elejéig a vizsgálatok elsősorban egyes társadalmi csoportok leszakadását, ezáltal bizonyos városrészek marginalizálódását emelték ki (Ladányi 1993, Kovács 1998). A 2000-es évtized derekától a kutatások súlypontja áttevődött a fizikai és társadalmi felértékelődés kutatására, melyek a városrehabilitáció hatásaira irányultak (Földi 2006, Egedy 2007, Timár-Nagy 2007). Utóbbi jelenséggel is magyarázható, hogy az elemzések földrajzi kerete a városi szint felől a városrészi szint felé tolódott. Hasonló felértékelődési folyamatokról számolt be számos tanulmány más posztszocialista nagyváros belvárosi területeinek átalakulása kapcsán. Ezek között a városok között említhetô például Vilnius (StandlKrupickaite 2004) és Prága (Sýkora 2009).

Budapest jelenlegi térbeli-társadalmi szerkezete szorosan összefügg a topográfiájával, amely lényegesen különbözik a város nyugati (hegyvidék, lazább beépítésû) és keleti (sík, sûrú beépítésű) fele között. Általánosságban megállapítható, hogy a budapesti városrészek társadalmi-gazdasági státusa nyugatról kelet felé csökken, kivételt képeznek a pesti oldal földrajzi perifériáján fekvő, jelentôs részben a belső szuburbanizációval érintett kertvárosi területek, ahol a lakosság jövedelmi, gazdasági státusa magasabb a belsőbb fekvésű városrészekénél.

Az 1950-es és az 1960-as évek politikája Budapesten kisebb társadalmi elkülönüléshez vezetett. A lakóhelyi szegregáció azonban a gazdaság és a lakásrendszer liberalizációjával kezdett növekedni, már az 1970-es évektől (Kovács et al. 2013). Budapestet a korai és nagyarányú lakásprivatizáció, továbbá a szocializmusban a többi posztszocialista nagyvároshoz képest viszonylag magas szegregáció és decentralizált városi kormányzás jellemzi (Tasan-Kok 2006). Marcińczak és szerzőtársai (2015) szerint a kelet-közép-európai posztszocialista fôvárosok közül Budapest a legszegregáltabb. A nyugati típusú nagyvárosokhoz hasonlóan a posztszocialista

Területi Statisztika, 2019, 59(6): 606-643; DOI: 10.15196/TS590602 
városokban is erősebb a legmagasabb társadalmi-gazdasági státusú csoportok térbeli elkülönülése, mint az alacsonyabb státusú társadalmi csoportoké (Ladányi 1989, Kovács 2009, Marcińczak et al. 2013).

A posztszocialista fővárosok és így Budapest társadalmának szegregációs profilja megközelíti a szabálytalan U-alakú mintát, és ezáltal összhangban van a térbelitársadalmi eloszlásban megfigyelhető általános tendenciákkal.

Budapesti sajátosság, hogy a magas társadalmi-gazdasági státusú körzetek jelentős csoportosulása mutatható ki (például a Budai-hegyekben, kisebb részben a pesti belvárosban). Ugyanakkor a legelterjedtebb városnegyedtípust a kevert társadalmigazdasági státusú körzetek alkotják. Ebbe a kategóriába sorolhatók egyrészt a belvárosi lakóterületek, amelyek esetében a lakóhelyi keveredés néhány fontos mikroszintú jellemzőt rejt magában (Kovács et al. 2013). A kevert státusú lakóegységek tipikus városrészei között megtalálhatók a belsőbb fekvésű, magasabb presztízsû́ lakótelepek: például a budai oldalon a III. kerületi Óbudai-lakótelep, Újbudán az Örmezői és a Kelenföldi lakótelep, a pesti oldalon a XIII. kerületben az Újlipótvárosi lakótelep vagy éppen a ferencvárosi József Attila lakótelep. Szintén a kevert státusú városrészek közé tartozik néhány sajátos arculatú és társadalmi összetételű korai generációs lakótelep is (például a józsefvárosi Tisztviselőtelep, a kispesti Wekerletelep).

Az alacsony, az alacsony-közepes státusú lakóterületek alapvetően a fôváros pesti oldalán koncentrálódnak, azon belül is elsősorban a külsô, városperemi városrészekben, valamint a belvároshoz közeli leromlott bérházas, rosszabb minőségú panellakótelepeken, továbbá az átmeneti övezet ipari-barnamezős területei közé ékelődő lakóegységeiben. Ezek között a területegységek között megfigyelhetőek az alacsonyabb státusú lakótelepek városrészei, a budai oldalon kivételt jelentő Békásmegyeri lakótelep területe, valamint a pesti oldalon Józsefváros, Újpest, Angyalföld lakótelepi városrészei, továbbá a fôváros perifériáján elhelyezkedő családi házas lakóterületek. Középső-Józsefváros számos lakónegyede (például Magdolna negyed, Orczy negyed) a mai napig az alacsonyabb társadalmi-gazdasági státusú területekhez tartozik Budapesten belül (Csanádi et al. 2010, Szabó 2007, Berényi 2010, Csizmady 2011).

Budapest és ezen belül Józsefváros esetében kevésbé jellemző olyan mértékú etnikai heterogenitás, mint számos nyugat-európai nagyvárosban. Mindazonáltal kétségtelen, hogy Budapest Kelet-Közép-Európa egyik legváltozatosabb városa. Hazai viszonylatban a vándorlás egyik fó célpontja, ahol a nem magyar nemzetiségú népesség aránya magasabb, mint az országos átlag, vagy a posztszocialista országok más nagyvárosában. Budapesten belül Józsefváros társadalma különösen változatos, melyben szerepet játszik, hogy a VIII. kerület hagyományosan a külföldről vagy az ország más részeiből ide költözők célterülete ("kapuja") volt. Józsefvárosban a nem magyar nemzetiségúek és az alacsony társadalmi-gazdasági státusúak átlagosnál magasabb koncentrációja jellemző (Fabula et al. 2017a, b).

Területi Statisztika, 2019, 59(6): 606-643; DOI: 10.15196/TS590602 


\section{Módszertan}

A nagyvárosi társadalmak növekvő sokszínúségének felismerése arra világít rá, hogy új társadalomföldrajzi megközelítésre van szükség a különböző társadalmi csoportok városban való együttélésének megértése, vizsgálata szempontjából. A sokszínúség jellemzőinek feltárásához, jelenségeinek megértéséhez komplex módon érdemes közelíteni. Egy szúkebb városi térben (például városnegyedben) a jövedelmi vagy etnikai alapon kevert csoport tagjai földrajzi értelemben egymás közelében élnek, ugyanakkor a különböző életstílusból, attitűdből és aktivitásból származó társadalmi távolság miatt csak ritkán találkoznak egymással. A hagyományos megközelítésú kutatási módszerek gyakran ragaszkodnak a merev, éles vonallal elválasztott társadalmi kategóriákhoz, földrajzi egységekhez, így figyelmen kívül hagyják a hiperdiverzifikált térbeli-társadalmi valóságot. Tanulmányom a kvantitatív módszerek korlátjaira is ráirányítja a figyelmet, ezért a statisztikai alapú vizsgálataim eredményeit kvalitatív kutatásaim eredményeivel egészítem ki.

\section{A mintaterület bemutatása}

Az esettanulmány mintaterülete a földrajzilag Budapest középső részén fekvő VIII. kerület. Józsefváros területének nagy része a történelmi belváros részét képezi. A kerület relatív kis kiterjedése $\left(6,85 \mathrm{~km}^{2}\right)$ ellenére egyike a fóváros társadalmilag és etnikailag legváltozatosabb, egyúttal leglátványosabban átalakuló területeinek. A 2016. évi mikrocenzus adatai szerint a kerület lakosságszáma 78 ezer 327 fő. Józsefváros térbeli-társadalmi tagoltsága, sokszínúsége jórészt történeti, illetve földrajzi okokra vezethetô vissza. A kerület társadalmilag meglehetősen heterogén volt már a kialakulásakor is. A Palotanegyed (2. ábra) - korábbi arisztokratanegyedként - máig sok mindent megőrzött korábbi jellegzetességei közül.

A Baross utca környezete (Csarnok negyed) tipikus pesti bérházakkal épült be. Gyengébb minőségú épületállomány alakult ki a mai Corvin negyed területén, ahol a bérházépitési láz is hamar alábbhagyott. Még szegényesebbek a mai Fiumei út (egykori városárok) mentén fekvő területek, ahol a lakófunkció mellett a gazdasági tevékenységek is nagyobb számban megtelepültek (például Magdolna, Ganz negyed). A kiegyezést követő urbanizációs fejlődés eredményeként a kerület belső részei a történelmi belváros szerves részévé váltak. Ugyanakkor a városrobbanás időszakában kialakult külső városrészeket Budapest átmeneti övének részeként a mozaikosság, a kiterjedt ipari-barnamezős területek jelenléte jellemezte. Józsefváros a Nagykörút XIX. század végi kiépülésével vált összefüggő városrésszé, azonban ez az egységesség inkább csak a városszerkezetben jelentkezett.

Területi Statisztika, 2019, 59(6): 606-643; DOI: 10.15196/TS590602 
Józsefváros negyedei

The residential areas of Józsefváros

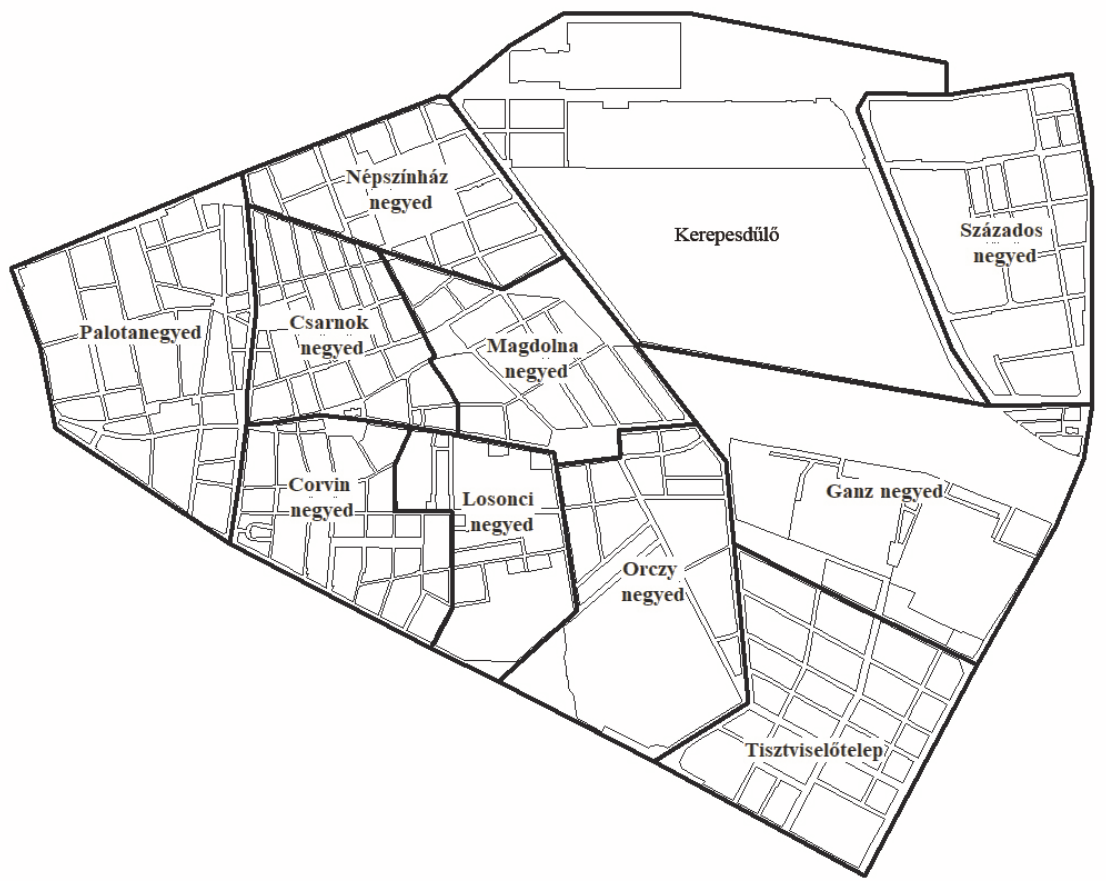

Forrás: Sárkány et al. (2005) alapján saját szerkesztés.

A sajátos történelmi fejlődés következtében Józsefváros, beleértve az épített környezetet, a helyi társadalmat és gazdaságot is, nagyon heterogén képet mutat. A kerület történelmében mind a sokszínúbbé válás, mind a homogenizálás időszakai jól azonosíthatók, amelyek a különböző belső és külső tényezők kölcsönhatásának következményei (például a XIX. század végi tőkés modernizáció, a világháborús időszakok stagnálása, a rendszerváltozást követő globalizálódás). Általában Budapesten a második világháború és az azt követő államszocialista idôszak negatívan hatott a társadalmi sokszínűségre. A rendszerváltozás óta új folyamatok figyelhetôk meg (például transznacionális tôke beáramlása, növekvő nemzetközi vándorlás, városrehabilitáció, dzsentrifikáció, bővülő idegenforgalom). Részben ezzel összefüggésben a különböző társadalmi-gazdasági csoportok együttélése fontos jellemzője a budapesti és különösen a józsefvárosi társadalomnak.

Józsefvárosban a külföldről érkező bevándorlók aránya magasabb az átlagosnál, különösen a Délkelet-Ázsiából és Afrikából érkezőké, és hatásuk a városképen is meglátszik, legerőteljesebben az etnikai enklávék, illetve az etnikai hátterú vállalkozások létrejöttével (Kohlbacher-Protasiewicz 2012). Ugyanakkor számos, a sokszínûség ellen ható tényezô ma is fennáll (például lakáspiaci kirekesztés, szegregáció).

Területi Statisztika, 2019, 59(6): 606-643; DOI: 10.15196/TS590602 
Napjainkban Józsefváros lakossága igen sokszínú a jövedelmeket, a társadalmi státust, az etnikai és a nemzeti hovatartozást, a kultúrát vagy éppen az életstílust, az értékrendet tekintve (Boros-Fabula 2017), ezért megfelelő mintaterületként szolgál a diverzitáskutatás számára. A kerületben továbbá az elmúlt két évtizedben több integrált városrehabilitációs programot is megvalósítottak (Corvin Sétány Program, korábbi nevén Corvin-Szigony Projekt, 2002; Magdolna Negyed Program, 2005; Európa Belvárosa Program, 2007) (3. ábra). Emiatt különösen indokolt a társadalmi hatások közül a társadalmi keveredést és az eltérő modellek szerint végrehajtott városrehabilitációs beavatkozások különböző hatásainak vizsgálata.

Józsefváros integrált városrehabilitációs programjainak területei

The areas of the integrated urban renewal programmes in Józsefváros

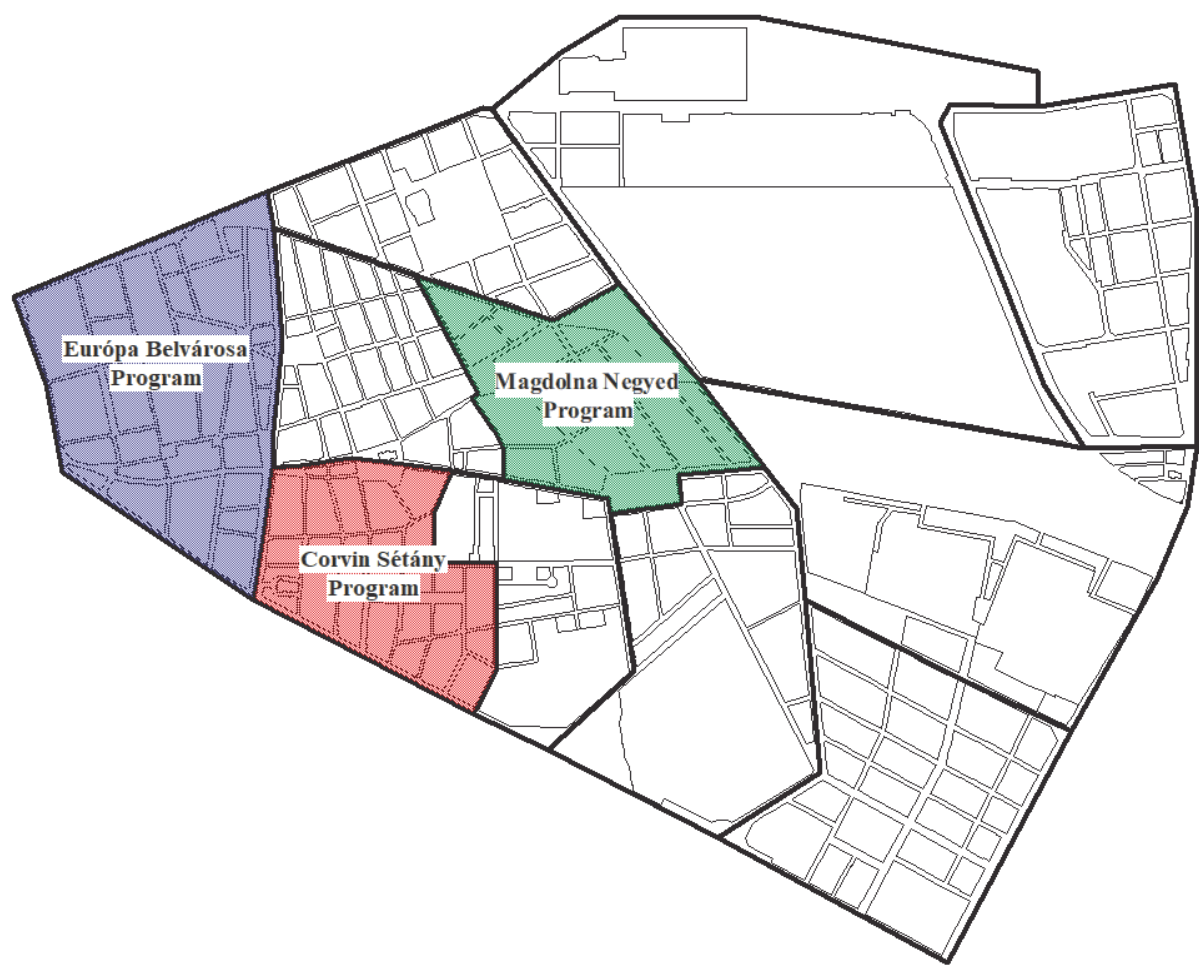

Forrás: Alföldi et al. 2007 alapján saját szerkesztés.

Az elmúlt években az Orczy negyed területén is jelentős városmegújitási folyamatok (például Ludovika Campus, szociális városrehabilitáció) bontakoztak ki, azonban a különböző beavatkozások még kezdeti szakaszban járnak, valamint nem alkotnak a városrészre egységesen kiterjedő városrehabiliációs programot. Az említett negyed a vizsgálatokban sem emelkedett ki, emiatt a 3. ábrán sem jelenik meg önállóan.

Területi Statisztika, 2019, 59(6): 606-643; DOI: 10.15196/TS590602 


\section{A kvantitatív módszerek ismertetése}

A társadalmi sokszínűség tanulmányozása során a kvantitatív elemzési módszerek közül a lakosság munkaerőpiaci szegmentációjának vizsgálatát, továbbá a disszimilaritási index és a szegregációs index számítását végeztem el. Józsefváros rendszerváltozás utáni térbeli-társadalmi szerkezetének feltárásához a Központi Statisztikai Hivatal (KSH) 1990., 2001., valamint 2011. évi népszámlálási, valamint a Budapesti Statisztikai Adatok Rendszerének (B-STAR) adatait vettem alapul.

A földrajzi vizsgálatot több területi szinten végeztem el. A legalacsonyabb területi szintet képviselő egységeket 77 körzet képezte. A mikrokörzetek lehatárolása az adott kerületrész településmorfológiai jellege és a városszerkezeti adottságok alapján történt, figyelembe véve a lakosságszám kiegyenlített (ezer fő/körzet) jellegét. A tömböknél nagyobb, viszont a városrészeknél kisebb földrajzi egységek lehatárolását indokolja, hogy a tanulmány célja Józsefváros térbeli-társadalmi mozaikosságának minél pontosabb meghatározása. A 1990., a 2001. és a 2011. évi népszámlálási adatok megfelelő térbeli felbontásban álltak rendelkezésre. A statisztikai alapú vizsgálatot a tizenegy városnegyed szintjén is elvégeztem. A mezoszintú egységek azok a városrészek voltak, amelyeket Józsefváros 2005-ben elfogadott kerületfejlesztési stratégiájában határoztak meg (Sárkány et al. 2005) (lásd 2. ábra).

Az elemzés során kitértem Budapest sokszínúségére is, melyhez elsősorban Kovács és Szabó (2016) tanulmányát vettem alapul.

\section{A munkaerópiaci szegmentáció vizsgálata}

A társadalmi szegregáció időbeli változásának mérésére foglalkoztatási adatokat használtam, amelyek a rendszerváltozást követô mindhárom népszámlálás időpontjában rendelkezésre álltak, így lehetôség nyílt a társadalmi változások hosszabb távú elemzésére. A foglalkozás a társadalmi-gazdasági státus meghatározásának széles körben elfogadott indikátora, valamint segítségével meghatározható az egyén társadalmi hierarchiában betöltött szerepe is (Morgan 1980). A foglalkozási típusok meghatározására a Foglalkozások Egységes Nemzetközi Osztályozási Rendszerének (International Standard Classification of Occupations - ISCO) felosztását alkalmaztam. Az ISCO az egyik legelfogadottabb osztályozás a munkaerőpiac tagolódásának vizsgálatára, továbbá a kelet-közép-európai országokban a jövedelmi különbségek és a társadalmi egyenlőtlenségek, továbbá ebből adódóan a posztszocialista társadalmigazdasági rétegződés feltárására (Smith et al. 2008, Marcińczak et al. 2012).

A társadalmi státuson alapuló szegregációs minták elemzéséhez nyolc foglalkozási csoportot használtam fel, ugyanis a kerület társadalmi sajátosságaihoz igazodva két foglalkozási csoportot elhagytam. Józsefvárosban a mező-, erdőgazdálkodás, halászati ágazatban elhanyagolható a foglalkoztatottak száma, valamint a fegyveres eróknél szolgálatot teljesítők aránya is radikálisan visszaesett a rendszerváltozást követôen. E két foglalkozási csoport nullához közeli arányának elhagyásával nem torzulnak

Területi Statisztika, 2019, 59(6): 606-643; DOI: 10.15196/TS590602 
az elemzés eredményei. Az ISCO-nómenklatúra a foglalkozási csoportokat négy képzettségi szinthez rendeli. A kategorizálást továbbvezetve a társadalmi-gazdasági elkülönülés, valamint a társadalmi keveredés elemzéséhez a nyolc foglalkozási csoport alapján három társadalmi-gazdasági státus szerinti kategóriát képeztem (1. táblázat).

\section{Az összevont foglalkozási csoportokból képzett}

1. táblázat társadalmi-gazdasági státus szerinti kategóriák

The socio-economic status related categories formed from the merged employment groups

\begin{tabular}{c|l|c}
\hline $\begin{array}{c}\text { Sor- } \\
\text { szám }\end{array}$ & \multicolumn{1}{|c|}{ ISCO-08 foglalkozási csoportok } & $\begin{array}{c}\text { Összevont társadalmi-gazdasági státus } \\
\text { szerinti csoportok }\end{array}$ \\
\hline 1. & Vezetők & Magas státusú \\
2. & Értelmiségiek & Közepes státusú \\
\hline 3. & Technikusok & \\
4. & Hivatalnokok & Alacsony státusú \\
\hline 5. & Szolgáltatók & \\
6. & Iparosok & \\
7. & Gépkezelők & Szakképzetlenek
\end{tabular}

\section{Indexszámítások}

A helyi társadalom térbeli mintázatát a szegregációs és a disszimilaritási index számításával mutattam ki. Ezek jelzik egyrészt a lakóhelyi elkülönülés mértékét, másrészt rávilágítanak arra, hogy mely társadalmi-gazdasági különbségek esetében jellemzők a földrajzi távolságok. A társadalomföldrajz a Hoover-index logikáját használja leggyakrabban a társadalmi csoportok térbeli koncentrálódásának, egymástól való lakóhelyi elkülönülésének elemzésére. Disszimilaritási indexnek $\left(\mathrm{D}_{\mathrm{AB}}\right)$ nevezzük abban az esetben, ha két népességcsoport területi elhelyezkedésének különbségét mérjük fel (Duncan-Duncan 1955, Probáld 1975, Beluszky 1992, Nemes Nagy 1998). Az index segítségével két társadalmi (például foglalkozási, etnikai) csoport földrajzi távolságát, azaz a megoszlásukban fellelhető különbséget határozhatjuk meg. A statisztikai értelmezés szerint két társadalmi csoport között akkor nincs szegregáció, ha a két csoport mindegyik területi egységben azonos arányban van jelen (az index értéke 0). Minden más esetben a két csoport valamilyen mértékű szegregációja figyelhető meg. Szélsőséges esetben az index értéke 1. A térbeli elkülönülés mellett ezzel a módszerrel térképezhetjük fel a társadalmi csoportok közötti keveredést is.

Területi Statisztika, 2019, 59(6): 606-643; DOI: 10.15196/TS590602 
A disszimilaritási index képlete:

$$
\mathrm{D}_{\mathrm{AB}}=\frac{1}{2} \sum_{i=1}^{n}\left|\frac{x_{i}}{\mathrm{X}}-\frac{y_{i}}{\mathrm{Y}}\right|
$$

ahol:

$x_{1}-\mathrm{az}$ „A" társadalmi csoport létszáma $i$ területegységen belül,

$y_{\mathrm{i}}-\mathrm{a}$ „B” társadalmi csoport létszáma $i$ területegységen belül,

$\mathrm{X}-\mathrm{az}, \mathrm{A}$ ” társadalmi csoport összlétszáma,

Y - a „B” társadalmi csoport összlétszáma,

$\mathrm{n}$-i - a területegységek száma.

A szegregációs index egy adott társadalmi (például foglalkozási, etnikai) csoportnak az összes többihez viszonyított elkülönülését adja meg. Esetében először kiszámoltam az adott társadalmi csoport és a teljes népesség disszimilaritási indexét, majd ezt elosztottam az adott csoport és a teljes népesség 1-ből kivont hányadosával.

A szegregációs index képlete:

$$
S=\frac{D_{s}}{1-\frac{\sum x_{a i}}{\sum x_{n i}}}
$$

ahol:

$D_{\mathrm{s}}$ - az adott társadalmi csoport disszimilaritási indexe,

$x_{\mathrm{ai}}-$ az adott társadalmi csoport összlétszáma,

$x_{\mathrm{ni}}-\mathrm{a}$ teljes népesség létszáma.

\section{A kvalitatív módszerek bemutatása}

A 2014 és 2016 között végzett kutatás során 50 kerületi lakossal és 40 vállalkozóval, gazdasági kulcsszereplővel készítettem félig strukturált mélyinterjút. A józsefvárosi lakosság és vállalkozások sokszínúségének minél pontosabb feltérképezése érdekében az interjúalanyokat különböző csatornákon keresztül választottam ki. Egyrészt a kerületi munkám során megismert személyek jelentették a potenciális interjúalanyok csoportjának magját, másrészt a baráti és az ismerősi kapcsolataik. Összességében az 50 lakossági interjúalany 40\%-a (20 fó) köthető közvetlenül a Rév8 Zrt.-nél folytatott munkámhoz és 20\%-a (10 fö) az ismerősi körhöz.

A kiválasztás során törekedtem arra, hogy a lakóhely, az életkor, a nem, a képzettség és a foglalkozás szempontjából a megkérdezettek csoportja leképezze a kerületi lakosság sokszínűségét. A további interjúalanyok hólabdamódszerrel kerültek be a mintába. A vállalkozások harmadát egy lakossági kulcsszemély közvetítésével, másik harmadát a kerületben végzett munkámból származó ismertségen keresztül értem el. A vállalkozások esetében a hólabdamódszer korlátozottan érvényesült, az etnikai hátterű vállalkozásokat pedig közvetítők nélkül, spontán, az utcáról belépve kérdeztem meg.

Területi Statisztika, 2019, 59(6): 606-643; DOI: 10.15196/TS590602 


\section{Eredmények}

\section{A munkaerőpiaci szegmentáció vizsgálatának eredményei}

Józsefvárosban a munkavállalók foglalkozási csoportok szerinti megoszlása, és ezáltal a kerület lakosságának társadalmi-gazdasági szerkezete a rendszerváltozás óta jelentősen átalakult (2. táblázat). Megállapítható, hogy bár a vezetők aránya a foglalkoztatottakon belül némileg csökkent 1990 és 2011 között, az értelmiségiek csoportjának aránya jelentôsen bóvült. Utóbbi tendencia magyarázza, hogy összességében a magas státusúak társadalmi-gazdasági csoportjának aránya 23-ról 31\%-ra emelkedett a vizsgált időszakban. Összehasonlításként Budapesten azonos időszakban 26-ról 34\%-ra emelkedett a magas státusúak aránya, ami azt mutatja, hogy a kerület a relatív helyzetén nem tudott javítani 1990 és 2011 között, a fővárosi átlagtól továbbra is közel azonos mértékű a lemaradása.

A helyi társadalom szegmentációjának alakulása

2. táblázat

Development of the segmentation of the local society

\begin{tabular}{|c|c|c|c|c|c|c|}
\hline \multirow{2}{*}{$\begin{array}{l}\text { ISCO-08 foglalkozási } \\
\text { csoportok }\end{array}$} & \multicolumn{2}{|c|}{1990} & \multicolumn{2}{|c|}{2001} & \multicolumn{2}{|c|}{2011} \\
\hline & fö & $\%$ & fö & $\%$ & fö & $\%$ \\
\hline 1 Vezetők & 2934 & 8,1 & 2320 & 7,4 & 2195 & 6,4 \\
\hline 2 Értelmiségiek & 5400 & 14,9 & 5992 & 19,0 & 8350 & 24,2 \\
\hline 3 Technikusok & 5924 & 16,3 & 5857 & 18,6 & 6808 & 19,8 \\
\hline 4 Hivatalnokok & 4364 & 12,0 & 2863 & 9,1 & 3489 & 10,1 \\
\hline 5 Szolgáltatók & 2910 & 8,0 & 5661 & 18,0 & 5276 & 15,3 \\
\hline 6 Iparosok & 6581 & 18,1 & 4485 & 14,3 & 2749 & 8,0 \\
\hline 7 Gépkezelők & 3644 & 10,0 & 1489 & 4,7 & 1503 & 4,4 \\
\hline 8 Szakképzetlenek & 4591 & 12,6 & 2786 & 8,9 & 4061 & 11,8 \\
\hline Összesen & 36348 & 100,0 & 31453 & 100,0 & 34431 & 100,0 \\
\hline \multicolumn{7}{|c|}{ Társadalmi-gazdasági csoportok } \\
\hline Magas státusúak & 8334 & 22,9 & 8312 & 26,4 & 10545 & 30,6 \\
\hline Közepes státusúak & 10288 & 28,3 & 8720 & 27,7 & 10297 & 29,9 \\
\hline Alacsony státusúak & 17726 & 48,8 & 14421 & 45,8 & 13589 & 39,5 \\
\hline
\end{tabular}

Forrás: KSH 1990., 2001. és 2011. évi népszámlálás adatai alapján saját szerkesztés.

Jelentős a változás az alacsonyabb presztízsű foglalkozási csoportok esetében is mind fôvárosi, mind kerületi szinten. A legnagyobb csökkenést a foglalkozási csoportok között az ipari dolgozók könyvelhették el a rendszerváltozást követő időszakban. A VIII. kerületen belüli részarányuk 18,1-ról 8,0\%-ra esett vissza, míg Kovács és Szabó (2016) kutatása szerint a fővárosi átlag 20,0-ról 8,5\%-ra csökkent. Józsefvárosra vonatkozóan kimutatható volt tehát a hagyományos iparos réteg zsugorodása, valamint a kerület „munkás” jellegének elvesztése.

Területi Statisztika, 2019, 59(6): 606-643; DOI: 10.15196/TS590602 
A gépkezelők és javításban dolgozók aránya is hasonló mértékben csökkent, így összességében nem véletlen, hogy az alacsony státusúak aránya Józsefvárosban 48,8ről 39,5\%-ra zsugorodott, ami még így is 6 százalékponttal haladta meg az alacsony státusúak fővárosi átlagát. A három legmagasabb és a három legalacsonyabb presztízsű foglalkozási csoport munkaerőpiacon belüli részesedésének aggregálása szintén jelentős átalakulásra enged következtetni. Józsefvárosban a legmagasabb presztízsű három foglalkozási csoportban foglalkoztatottak aránya 1990 és 2011 között 39,3ről 50,5\%-ra emelkedett, jelentősen elmaradva a fôvárosi szintű emelkedés mértékétől (42,6-ről 55,9\%-ra). Azonos időszak alatt az alsó három foglalkozási csoport munkavállalóinak aránya jelentősen, 40,7-ről 24,2\%-ra csökkent Józsefvárosban, de még mindig számottevően magasabb a fővárosi átlagnál (21,0\%).

A józsefvárosi lakosság munkaerôpiaci szegmentációjának vizsgálata alapján a társadalmi-gazdasági csoportok között egy felfelé tolódás figyelhető meg, amely egybevág a nemzetközi tendenciákkal. Ennek okai elsősorban a gazdasági paradigmaváltást kísérő dezindusztrializáció és a szolgáltató munkahelyek bővülése, valamint a professzionalizáció. A fốvárosi - beleértve a kerületi - lakosság jelentős foglalkozási átrétegződésének oka egyrészt a gazdasági szerkezetváltás, másrészt a lakosság iskolázottsági szintjének jelentős emelkedése (Kovács-Szabó 2016). Józsefváros társadalma jelentősen átalakult 1990 és 2011 között, és a társadalmi státus alapján a fóvárosi átlaghoz való felzárkózás jeleit mutatta. Ugyanakkor fővárosi viszonylatban a VIII. kerület továbbra is egy kevésbé fejlett, a budapesti átlagtól elmaradó városrész volt 2011-ben.

A 2014 és 2017 között zajló saját interjús kutatás alapján feltételezhető, hogy Józsefvárosban az egyetemek közelsége és a városrehabilitáció hatására kibontakozó fokozott studentifikáció következtében a 2011. évi adatokhoz képest a lakosság iskolai végzettsége, munkaerôpiaci pozíciója jelentősen javult. A kerület társadalmigazdasági felzárkózásának folyamatát támasztják alá hazai szakirodalmi eredmények mellett (Egedy 2008, Alföldi-Horváth 2009, Boros et al. 2016, Boros-Fabula 2017) az utóbbi évek ingatlanpiaci (például OTP Lakóingatlan Értéktérkép, az OTP Jelzálogbank Nyrt. elemzései) és munkaerôpiaci statisztikái (például Nemzeti Foglalkozási Szolgálat jelentései) is. A munkaerőpiaci szegmentáció vizsgálatát a városnegyedek szintjén is elvégeztem, melynek eredményeit a 4. ábra mutatja. A városnegyedekre aggregálást az indokolta, hogy a tanulmány a társadalmi sokszínúséget befolyásoló legfontosabb tényezôk között a városnegyedekre kiterjedő komplex városrehabilitációs programok hatásának feltárását célozza. 
A városrehabilitáció társadalmi sokszínúségre gyakorolt hatásainak térbeli-társadalmi vizsgálata Józsefvárosban

A munkavállalási korú népesség társadalmi státus szerinti megoszlása 1990 és 2011-ben

Distribution of the employment-aged population by social status in 1990 and 2011

1990

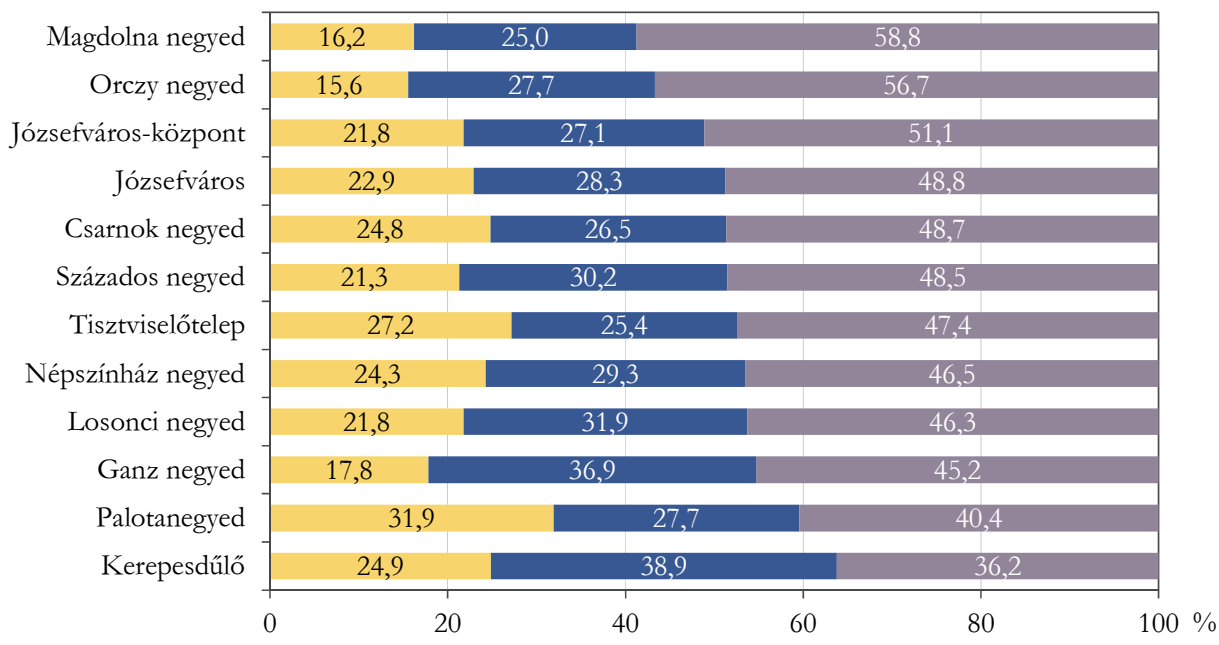

2011

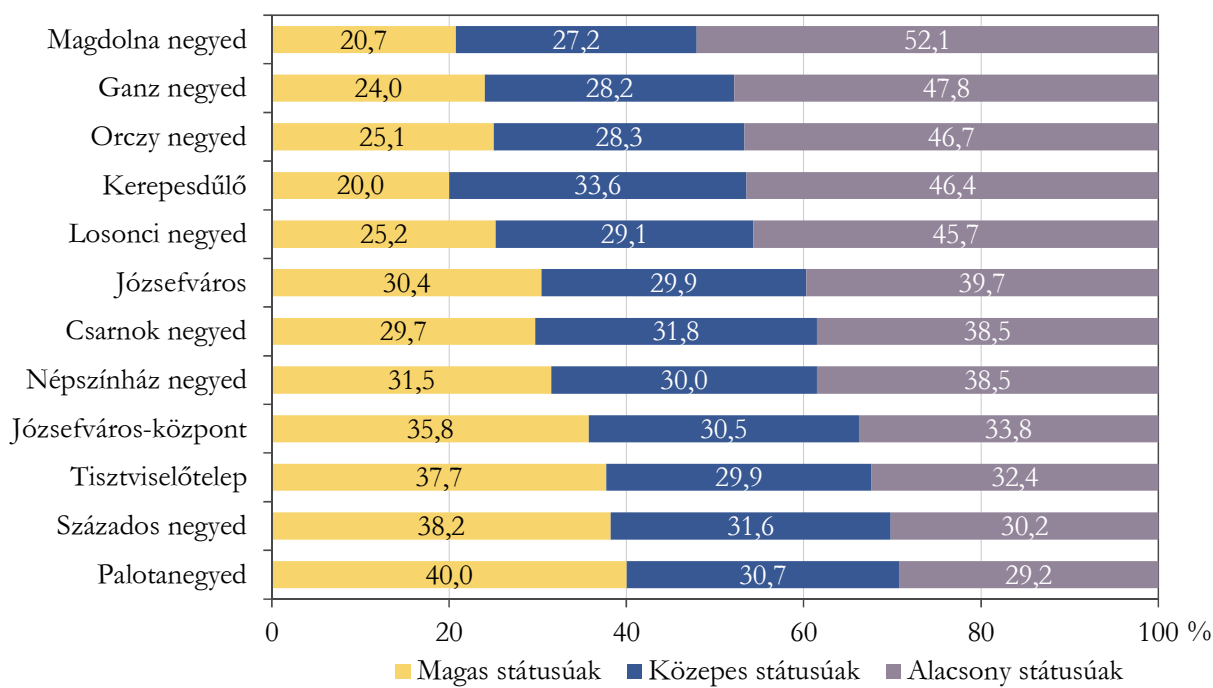

Forrás: KSH 1990, 2011. évi népszámlálás adatai alapján saját szerkesztés.

Területi Statisztika, 2019, 59(6): 606-643; DOI: 10.15196/TS590602 
A városnegyedek elemzésével kimutathatóvá váltak azok átalakulási folyamatai. Bár átlagosan jelentősen emelkedett Józsefváros lakosságának társadalmi státusa (az alacsony státusúak aránya 1990-ben 48,8, 2011-ben 39,5\%), a városnegyedek szintjén ez az emelkedés nagyon egyenlőtlen volt. A városnegyedek vizsgálata felhívta a figyelmet a városrehabilitáció különböző típusainak eltérő hatására. A Magdolna és az Orczy negyed esetében társadalmi-gazdasági státus alapján az átlagosnál kisebb mértékú volt a pozitív elmozdulás, ami e két negyed további leszakadására utalt.

Az Orczy negyed esetében a városrehabilitáció elmaradása magyarázta az említett eredményt, a Magdolna negyed esetében a szociális városrehabilitáció mérsékelte a leszakadást. Ugyanakkor a Corvin negyedben az ingatlanfejlesztő városrehabilitáció jelentősen átalakította a helyi lakosság társadalmi-gazdasági összetételét, melynek eredményeként felzárkózott a Palotanegyed szintjéhez. A társadalmi-gazdasági státus átalakulását vizsgáltam körzetszinten is (5. ábra). A helyi társadalom státusának változását négy kategóriába soroltam: romló, stagnáló, javuló és fejlődő. E vizsgálat valamelyest árnyalta a városnegyed szintú elemzés eredményeit, hiszen kimutatható volt, hogy a fejlődő negyedek is magukban foglalnak stagnáló (akár romló) lakókörnyezeteket, illetve a romló negyedekben is fellelhetők fejlődő körzetek (például a Magdolna negyedben a Mátyás tér és a Teleki tér környéke, az Orczy negyedben az Orczy tér környéke). Ezekben a különbségekben a városfelújítás negyedeken belüli, lokális hatása mutatkozott meg.

5. ábra

Józsefváros lakosságának társadalmi-gazdasági átalakulása, 1990 és 2011 között

Socio-economic changes in the Józsefváros population between 1990 and 2011

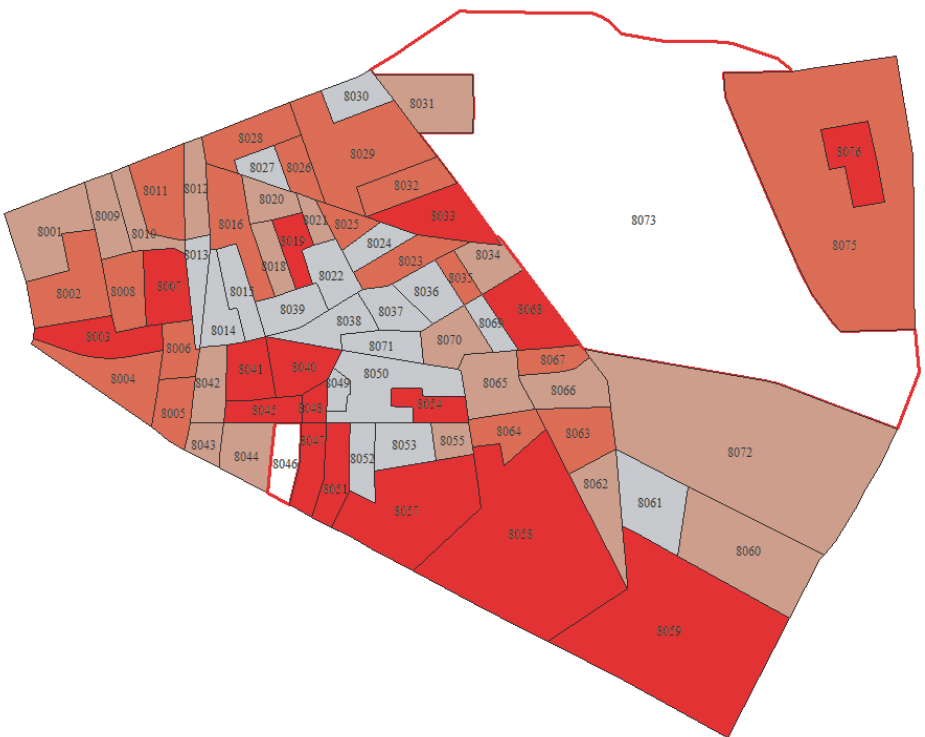

Fejlődő (16)

Javuló (18)

Stagnáló (19)

Romló (18)

Megjegyzés: az ábrán a népszámlálási körzetazonosítók szerepelnek.

Forrás: KSH 1990., 2011. évi népszámlálás adatai alapján saját szerkesztés.

Területi Statisztika, 2019, 59(6): 606-643; DOI: 10.15196/TS590602 


\section{A disszimilaritásiindex-számítás eredményei}

A kutatás keretében disszimilaritási indexet is számítottam a kerületben lehatárolt körzetekre, a társadalmi-gazdasági státus és a földrajzi távolság közötti összefüggések feltárása érdekében.

Az indexszámítás megmutatta (3. táblázat), hogy 1990 és 2001 között körzetszinten nőtt a különböző foglalkozási csoportok közötti térbeli elkülönülés, egyfajta homogenizáció ment végbe a helyi társadalomban. Ez összefügghet a kerület 1990-es évekbeli leromlásával, a szegregáció fokozódásával.

3. táblázat

\section{A disszimilaritási index értékének változása Józsefvárosban}

Changes in the dissimilarity index values in Józsefváros

\begin{tabular}{|c|c|c|c|c|c|c|c|c|}
\hline Index & 1 & 2 & 3 & 4 & 5 & 6 & 7 & 8 \\
\hline & \multicolumn{8}{|c|}{1990} \\
\hline $\mathrm{D}_{\mathrm{AB}} 1$ & \multirow[t]{8}{*}{0,00} & 0,10 & 0,13 & 0,18 & 0,18 & 0,20 & 0,22 & 0,25 \\
\hline $\mathrm{D}_{\mathrm{AB}} 2$ & & 0,00 & 0,14 & 0,18 & 0,19 & 0,20 & 0,21 & 0,24 \\
\hline $\mathrm{D}_{\mathrm{AB}} 3$ & & & 0,00 & 0,12 & 0,15 & 0,14 & 0,15 & 0,18 \\
\hline $\mathrm{D}_{\mathrm{AB}} 4$ & & & & 0,00 & 0,11 & 0,10 & 0,11 & 0,15 \\
\hline $\mathrm{D}_{\mathrm{AB}} 5$ & & & & & 0,00 & 0,11 & 0,14 & 0,16 \\
\hline $\mathrm{D}_{\mathrm{AB}} 7$ & & & & & & 0,00 & 0,10 & 0,11 \\
\hline $\mathrm{D}_{\mathrm{AB}} 8$ & & & & & & & 0,00 & 0,12 \\
\hline \multirow[t]{2}{*}{$\mathrm{D}_{\mathrm{AB}} 9$} & & & & & & & & 0,00 \\
\hline & \multicolumn{8}{|c|}{2001} \\
\hline $\mathrm{D}_{\mathrm{AB}} 1$ & \multirow[t]{8}{*}{0,00} & 0,11 & 0,14 & 0,17 & 0,22 & 0,24 & 0,26 & 0,33 \\
\hline $\mathrm{D}_{\mathrm{AB}} 2$ & & 0,00 & 0,14 & 0,19 & 0,24 & 0,24 & 0,26 & 0,32 \\
\hline $\mathrm{D}_{\mathrm{AB}} 3$ & & & 0,00 & 0,11 & 0,14 & 0,16 & 0,18 & 0,25 \\
\hline $\mathrm{D}_{\mathrm{AB}} 4$ & & & & 0,00 & 0,11 & 0,13 & 0,16 & 0,22 \\
\hline $\mathrm{D}_{\mathrm{AB}} 5$ & & & & & 0,00 & 0,11 & 0,14 & 0,19 \\
\hline $\mathrm{D}_{\mathrm{AB}} 7$ & & & & & & 0,00 & 0,11 & 0,15 \\
\hline $\mathrm{D}_{\mathrm{AB}} 8$ & & & & & & & 0,00 & 0,18 \\
\hline \multirow[t]{2}{*}{$\mathrm{D}_{\mathrm{AB}} 9$} & & & & & & & & 0,00 \\
\hline & \multicolumn{8}{|c|}{2011} \\
\hline $\mathrm{D}_{\mathrm{AB}} 1$ & 0,00 & 0,12 & 0,11 & 0,14 & 0,17 & 0,19 & 0,19 & 0,24 \\
\hline $\mathrm{D}_{\mathrm{AB}} 2$ & & 0,00 & 0,11 & 0,14 & 0,22 & 0,22 & 0,25 & 0,26 \\
\hline $\mathrm{D}_{\mathrm{AB}} 3$ & & & 0,00 & 0,10 & 0,13 & 0,14 & 0,16 & 0,19 \\
\hline $\mathrm{D}_{\mathrm{AB}} 4$ & & & & 0,00 & 0,13 & 0,13 & 0,15 & 0,16 \\
\hline $\mathrm{D}_{\mathrm{AB}} 5$ & & & & & 0,00 & 0,10 & 0,11 & 0,14 \\
\hline $\mathrm{D}_{\mathrm{AB}} 7$ & & & & & & 0,00 & 0,10 & 0,11 \\
\hline $\mathrm{D}_{\mathrm{AB}} 8$ & & & & & & & 0,00 & 0,14 \\
\hline $\mathrm{D}_{\mathrm{AB}} 9$ & & & & & & & & 0,00 \\
\hline
\end{tabular}

Megjegyzés: 1 - Vezetők, 2 - Értelmiségiek, 3 - Technikusok, 4 - Hivatalnokok, 5 - Szolgáltatók, 6 - Iparosok, 7 - Gépkezelők, 8 - Szakképzetlenek. A 0,20 és annál nagyobb értékeket szürke háttérrel emeltük ki.

Forrás: KSH 1990., 2001., 2011. évi népszámlálás adatai alapján saját szerkesztés.

Területi Statisztika, 2019, 59(6): 606-643; DOI: 10.15196/TS590602 
Míg 2001 és 2011 között a disszimilaritási index kerületi értékei csökkentek, ami a helyi társadalom keveredésére utal. Figyelemre méltó, hogy a területi eredmények jelentősen eltértek Kovács-Szabó (2016) fővárosiaktól, mely szerint Budapesten 1990 és 2011 között a térbeli elkülönülés egyes foglalkozási csoportok között fokozatosan erősödött, emellett egyre szélesebb körben bontakozott ki. Ez azt mutatja, hogy a VIII. kerület és a főváros térbeli-társadalmi folyamatai a társadalmi-gazdasági státust vizsgálva 2001-ben elváltak egymástól. 2001 és 2011 között Józsefvárosban a körzetek szintjén a helyi lakosság heterogenizációja, ezzel szemben Budapesten a homogenizáció bontakozott ki. Ebben vélhetően jelentős szerepet játszott Józsefváros átalakulása, a városrehabilitációs programok társadalmi hatása, a magasabb státusúak beköltözése (dzsentrifikáció).

A helyi társadalom heterogenitásának növekedését támasztotta alá a szegregációs index számítása is (6. ábra). A vizsgálat szerint a szegregáció mértéke Józsefvárosban jelentősen csökkent 2001 és 2011 között, és a csökkenő tendencia mellett a különböző társadalmi rétegek eltérő viselkedése figyelhetô meg. A városrehabilitáció hatására kibontakozó dzsentrifikáció folyamatára utalt, hogy 2011-ben a szegregáció mértéke már nagyobb volt a magasabb státusúak esetében, mint az alacsonyabb státusú csoportoknál. A szegregációs vizsgálat alátámasztotta azt a szakirodalomban ismertetett kutatási eredményt, mely szerint a szegregációs index értékei a társadalom alsó és felső rétegei esetében magasabbak (szegregációs görbe U-alakja).

A szegregációs indexek és görbe alakulása

6. ábra

Variations of segregation indices and curve

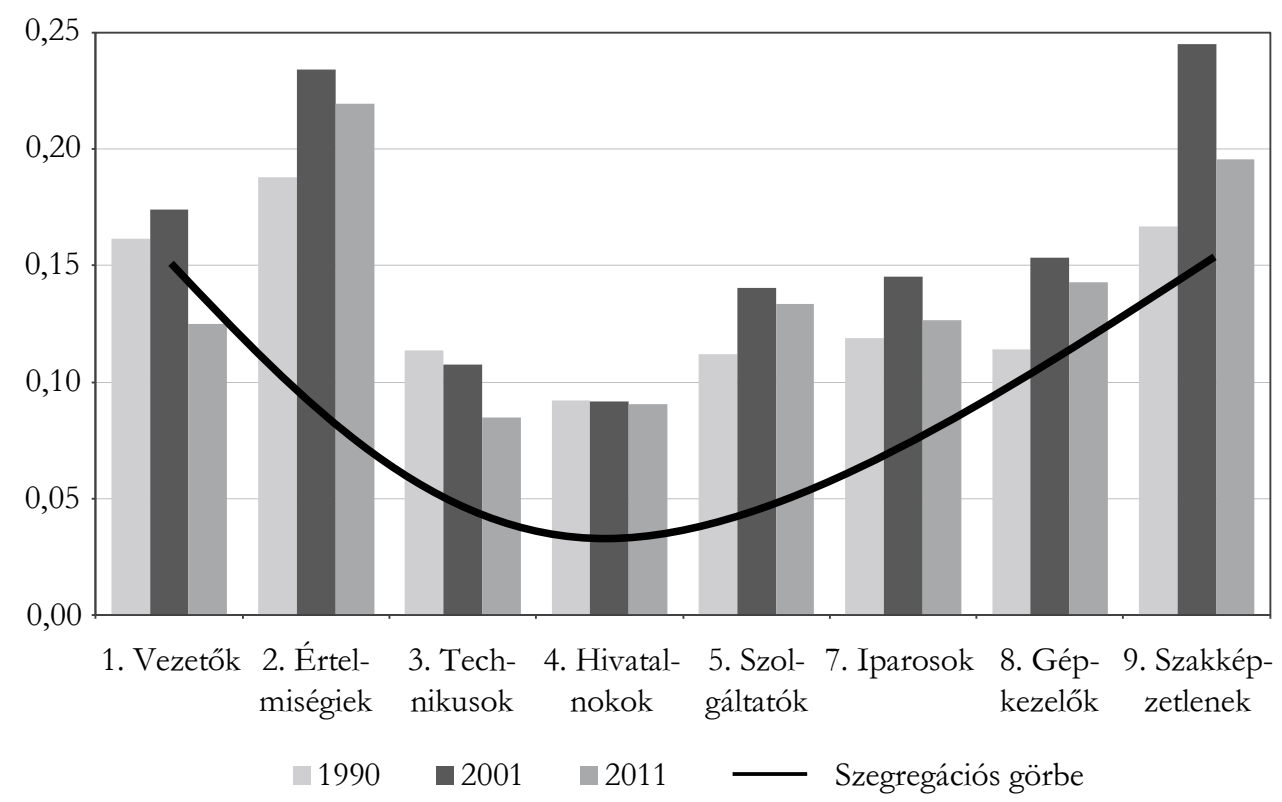

Forrás: KSH 1990., 2001., 2011. évi népszámlálás adatai alapján saját szerkesztés.

Területi Statisztika, 2019, 59(6): 606-643; DOI: 10.15196/TS590602 


\section{A kvalitatív vizsgálat eredményei}

A sokszínúség és a városrehabilitáció kapcsolatát, a pozitív és a negatív hatásokat a társadalmi kohézió, a társadalmi mobilitás és a gazdasági teljesítmény oldaláról vizsgáltam, a hiperdiverzitás koncepcióját követve (Tasan-Kok et al. 2013). A társadalmi kohézió esetében kiemelendő, hogy Budapesten a történelem során a más országokból és vidékről érkezők befogadása fontos szerepet játszott. A sokszínűség hagyományos értéknek volt tekinthető. Az államszocializmus évtizedei bizonyos mértékig erodálták ezeket a hagyományokat, de a rendszerváltozás óta a lakosság újra sokszínúbbé kezdett válni. A sokszínűség azonban gyakran negatív kontextusban jelenik meg, különösen a 2015. évi menekültválságot követően és elsősorban a társadalmi kohézió viszonylatában.

A megkérdezettek véleménye alapján a sokszínűség társadalmi kohézióra gyakorolt hatásai ellentmondásosak. Egyrészt Józsefváros hagyományosan befogadó kerület, ahol a szegénység mindig is jelen volt, és a kohézió, a szolidaritás mindig erősebb volt az alacsonyabb státusú és a régi lakosok körében. Másrészt a városrehabilitáció következtében kibontakozó dzsentrifikáció és studentifikáció által növekvő társadalmi sokszínúség gyengítette a társadalmi kohéziót, mivel a népességcsere a korábbi társadalmi kapcsolatok gyengüléséhez, olykor megszűnéséhez vezetett. A városrehabilitáció különböző típusai eltérô mértékben járultak hozzá a lakosság kicserélődéséhez, ezáltal a társadalmi kohézió változásához. A szociális városrehabilitáció a lakosság megtartására törekedett, így esetében a társadalmi kapcsolatok felbomlásának kisebb volt az esélye, sőt számos példa bizonyította, hogy a városrehabilitáció erősítette a kohéziót (például a lakosság bevonása a felújítási programokba, a közösségi tervezések megvalósítása, a lakossági és civil szerveződések létrejötte, a közösségi ház programjai).

A Corvin negyedet - és bizonyos tekintetben a Palotanegyedet is - a magas fokú társadalmi keveredés jellemzi, és esetükben jelentős kihívást jelentett a társadalmi kohézió gyengülése (például régi és új lakosok, alacsonyabb és magasabb jövedelmûek, helyiek és külföldiek között). Az interjúalanyok többsége úgy vélte, hogy a sokszínűség a kohézió gyengüléséhez vezet.

Ugyanakkor budapesti szinten a társadalmi kohézió szempontjából pozitív hatású, hogy Józsefváros a növekvő beköltözések és társadalmi keveredés következtében olyan aktív, magasabb státusú népességgel bővül, akik társadalmi kapcsolataik révén nagyobb részben Budapest más részeihez kötődnek. Ezáltal Józsefváros Budapesten belüli elkülönülése oldódhat.

Az interjúk egyrészt alátámasztják azokat a negatív előjelú nemzetközi kutatási eredményeket, melyek szerint a városrészek heterogenitása inkább gyengíti a kohéziót (Bolt-Van Kempen 2013; Bond et al. 2011). Másrészt a kutatás eredményei alapján az a pozitív következtetés vonható le, hogy a helyi társadalmi kohézió összehangolt, területileg koncentrált szakpolitikai intézkedésekkel (,jó kormányzással”) javítható.

Területi Statisztika, 2019, 59(6): 606-643; DOI: 10.15196/TS590602 
Hatékony intézkedéscsomag lehet a szociális városrehabilitáció, melynek megítélése az interjúk során pozitív volt. Általában a városrehabilitáció, különösen a kezdeti szakaszában, jelentősen növeli a társadalom heterogenitását, ezáltal rendszerint gyengíti a társadalmi kohéziót. Ugyanakkor lényeges hangsúlyozni a városrehabilitáció sokszínűségben játszott szerepét, ugyanis a városrehabilitációs beavatkozásokon belül a társadalmi, a szociális és a közösségfejlesztési elemek növekvő fontosságát, melyek tompíthatják a városrehabilitáció negatív hatásait, különösen a társadalmi kohézió szempontjából. Az integrált, szociális városrehabilitáció megfelelő eszköztárt kínál erre, hiszen egy rehabilitáció alatt álló városrészen belül az önkormányzati bérlakások megőrzése, felújítása, a helyben elérhető szociális és közösségi szolgáltatások megerősitése, bővitése, a lakosság bevonása a rehabilitációba hatékonyan járult hozzá az alacsonyabb fokú dzsentrifikációhoz, a különböző társadalmi csoportok (például nem, életkor, származás, társadalmi-gazdasági státus, végzettség) közötti interakciók kialakulásához (Alföldi et al. 2007, Alföldi-Horváth 2009, Horváth-Teller 2008, Horváth 2009, Horváth et al. 2018).

A Konrád és Szelényi (1971) által meghatározott késleltetett urbanizáció jelenségének analógiájára a szociális városrehabilitáció kapcsán megfogalmazható egy késleltetett (re)urbanizáació, ezáltal késleltetett dzsentrifikáció. E folyamaton azt értem, hogy a szociálisan érzékeny városrehabilitáció keretében nem a magasabb státusú beköltözők számára jönnek létre új lakóhelyek, hanem elsősorban a jelenlevő lakóközösség megerősítésére történnek erőfeszítések. Ugyanakkor az új vagy megújuló közösségi terek, létesítmények, intézmények és szolgáltatások kialakítása tekintetében már történnek olyan városrehabilitációs beavatkozások, amelyek alkalmassá, sőt akár vonzóvá is tehetik a rehabilitációval érintett városrészt, vagy annak egyes részeit. A Magdolna negyedben az említettek megvalósulását követően napjainkban magánbefektetők - saját beruházásaik révén - a magasabb státusúak beköltözését biztosító lakásállományt hoznak létre. Ez a mechanizmus lényegesen befolyásolja a társadalmi sokszínűség alakulását.

Az interjúk alapján nem állítható, hogy a sokszínűség egyértelműen pozitív hatással volt a józsefvárosi lakosság társadalmi mobilitására. A válaszadók a kerület társadalmi heterogenitását általában nem tekintették a társadalmi mobilitás fontos tényezőjének.

Különösen az alacsony státusú interjúalanyok esetében játszottak fontos szerepet a kerületen belüli kapcsolatok a társadalmi mobilitás szempontjából. A kerületi lakásállomány és a városi funkciók sokszínűsége lényeges tényező volt a társadalmi mobilitás szempontjából, melyre a városrehabilitációs programok jelentôs hatással voltak. Az alacsony színvonalú épületek aránya jelentős a kerületben, de a folyamatban lévô városrehabilitáció eredményeként nagyszámú új vagy megújított lakás áll rendelkezésre a helyi lakáspiacon.

A lakáspiaci sajátosságokkal összefüggésben (például az önkormányzati lakások magas aránya, a megfizethető lakásbérleti díjak, a viszonylag alacsony ingatlanárak) a

Területi Statisztika, 2019, 59(6): 606-643; DOI: 10.15196/TS590602 
Budapestre költözők közül sokan Józsefvárost választják belépési pontként. A kerület számos oktatási és álláslehetőséget kínál az újonnan érkezők számára, emiatt Józsefváros ún. ugródeszka-funkciót is betölt a fővároson belül. A helyi lakáspiac és a funkcionális sokféleség pozitívan járult hozzá a józsefvárosi társadalmi mobilitáshoz.

A kvantitatív vizsgálat talapján az a következtetés vontható le, hogy a társadalmi mobilitás és a sokszínűség közötti kapcsolat Józsefvárosban nem egyértelmú. A kutatás eredményei összhangban vannak azokkal az elemzésekkel (BrännströmRojas 2012, Galster et al. 2008, Gordon-Monastiriotis 2006, Urban 2009), amelyek szerint a személyes tényezők szerepe meghaladja a szomszédsági jellemzők fontosságát.

A budapesti lakosság átlagos mobilitási szintje jelentősen nőtt 1990 és 2011 között. Különösen igaz ez Józsefvárosra, ahol a dzsentrifikáció és a studentifikáció folyamata zajlik, jelentős népességváltozást és gyengébb társadalmi kapcsolatokat eredményezve (Fabula et al. 2017a, b). A helyi közösségi kezdeményezések támogatása és a lakosság bevonására irányuló programok megoldást jelenthetnek a helyi szomszédsági kapcsolatok erősítése szempontjából. A komplex városrehabilitációs programok ebben a tekintetben is központi szerepet töltenek be.

Az elemzés fontos tanulsága, hogy a városok számára a sokszínűség a társadalmi szempontok mellett a gazdasági teljesitmény növekedésének is lehetséges forrása. A helyi vállalkozókkal folytatott interjúk alapján megállapítható, hogy a kerület sokszínúsége nincs közvetlen hatással a vállalkozások megtelepedésére, de Józsefváros városrészei számos kedvező lehetőséget kínálnak a vállalkozók számára (például városközponti fekvés, megfizethető bérleti dijak, alacsony ingatlanárak, változatos kereslet). Más tényezők (például családi hagyományok, készségek, munkaerő-kínálat) felülmúlják a sokszínűség jelentőségét a vállalkozás indítása és a gazdasági teljesítmény vonatkozásában. Az eredmények összhangban vannak Komlósi-Páger (2015) korrelációs elemzésével. Ugyanakkor a megkérdezettek szerint mind a kereslet, mind a kínálat szempontjából a társadalmi sokszínűségnek érzékelhető a szerepe.

Keresleti oldalon a népesség átalakulása új termékeket és szolgáltatásokat generált, a kínálati oldalon a hagyományos és az újszerü, a kisvállalkozások és a nagyvállalatok keveredése növelte a vállalkozások sokszínűségét. Józsefvárosban miként a lakosságon belül az alacsony státusúak, úgy a vállalkozói szférán belül a kényszervállalkozók is felülreprezentáltak, emiatt a kisvállalkozások számára a siker többnyire a túlélést jelentette. Növekedett viszont a fejlődő vállalkozások száma, melyek jelentős részben a Corvin negyedben és környékén múködtek, ami megmutatta a városrehabilitáció helyi gazdaságra gyakorolt kedvező hatását.

A hagyományos kisiparos és kiskereskedő vállalkozások a stagnáló vagy romló helyzetük kialakulásának okai között ritkán említették a városrehabilitációt, sokkal inkább a makrogazdasági, a strukturális és a technológiai szempontok érintették hátrányosan őket. Józsefváros a magyar és a nem magyar vállalkozók számára első számú belépési pontot jelentett a budapesti piacra, mely sajátosságát a városrehabilitáció csak megerősítette.

Területi Statisztika, 2019, 59(6): 606-643; DOI: 10.15196/TS590602 


\section{Összegzés}

A rendszerváltozástól a 2011-ig tartó időszakot lefedő kvantitatív vizsgálataim a városrehabilitáció társadalmi hatásairól kimutatták, hogy Józsefváros lecsúszása a városmegújitó beavatkozásokat nélkülöző 1990-es években folytatódott, és a szegregáció növekedését a lakosság társadalmi-gazdasági homogenizációja kísérte. Ugyanakkor 2001 és 2011 között már a felzárkózás jelei mutatkoztak, a társadalmi sokszínúség erôsödése mellett.

A józsefvárosi lakosság munkaerôpiaci szegmentációjának vizsgálata alapján a magasabb státusúak arányának emelkedése megegyezett a fóvárosi átlaggal. Az alacsonyabb státusúak lakosságon belüli aránya a 2011-ig tartó időszakban jelentősen csökkent, de még így is a helyi társadalmon belüli részesedésük a fővárosi átlagot jelentősen (8 százalékpont) meghaladta. A kvantitatív vizsgálat alapján érzékelhetővé váltak a negyedek eltérő átalakulási folyamatai.

Az elemzés kimutatta, hogy a vizsgált időszakban bár jelentősen emelkedett Józsefváros lakosságának általános társadalmi státusa, ez a városnegyedek szintjén egyenlőtlenül ment végbe. A foglalkozási átrétegződés mértékének egyes negyedek közötti markáns különbsége szoros összefüggést mutatott az adott városrészben zajló városrehabilitációs beavatkozásokkal. A kutatás rámutatott arra is, hogy a makrogazdasági tényezők mellett a lokális jellemzők (például városrehabilitáció) meghatározó szerepet töltöttek be egyes városrészek státusának változásában. A beavatkozás jellegétől (például szociális városrehabilitáció, ingatlanfejlesztő rehabilitáció) függően eltérő társadalmi és gazdasági folyamatok indultak el a különböző lakónegyedekben, illetve a különböző társadalmi csoportok eltérő módon reagáltak a városrehabilitációra (például fiatalok beköltözése).

Az általános budapesti trendek Józsefvárosra is jellemzőek, de helyi sajátosság, hogy a kerület - még a homogenizáció időszakaiban is - az átlagosnál nagyobb mértékben megőrizte a sokszínűségét. Ehhez jelentős részben hozzájárultak az elmúlt két évtizedben városrészenként zajló komplex városmegújító programok. Míg a Corvin negyedben a 2000-es évek eleje óta tartó ingatlanfejlesztő típusú Corvin Sétány Program (korábbi nevén: Corvin-Szigony projekt) a dzsentrifikáció kezdeti folyamatai révén, addig a Magdolna negyedben a 2005 óta megvalósuló szociális városrehabilitáció (Magdolna Negyed Program) a helyi társadalmi sokszínűség megőrzésével járult hozzá annak a kerületi szintű markáns megőrzéséhez. Mindeközben a Palotanegyedben 2007 óta kibontakozó kulturális gazdaságfejlesztő városrehabilitáció (Európa Belváros Program) támogatta a kerület hagyományosan magas presztízsű városrészének a belvároshoz való felzárkóztatását, melyet a társadalmi hatások tekintetében a Corvin negyedhez képest kisebb mértékú, és jellemzően spontán módon kibontakozó dzsentrifikációs folyamatok kísértek. Mindemellett a városrész megújításának célja, hogy a sokszínűséget képviselje a budapesti belvárosi életben (Alföldi et al. 2007).

Területi Statisztika, 2019, 59(6): 606-643; DOI: 10.15196/TS590602 
Szintén a városrehabilitáció lokális hatását mutatták ki a disszimmilaritási és szegregációs indexek számításai. A fôvárosi trendekkel szemben Józsefváros lakosságán belül a 2000-es évektől növekvő heterogenitás figyelhető meg, a szegregáció csökkenése mellett. A kutatás szerint Budapest és Józsefváros térbeli-társadalmi folyamatai a társadalmi-gazdasági státust vizsgálva 2001 után elváltak egymástól. Ebben meghatározó szerepe volt a kerületben zajló városrehabilitációt kísérő dzsentrifikációnak és studentifikációnak, hiszen míg 1990-ben és 2001-ben a szegregáció mértéke az alacsonyabb státusú csoportok esetében volt nagyobb, addig 2011-ben már a magasabb státusúak esetében. A kedvező folyamatok ellenére Józsefváros relatív helyzete a fôvárosi átlaghoz képest 2011-ig lényegében nem változott.

Az 1990 és 2011 közötti statisztikai adatokon alapuló kvantitatív és az azt kiegészítő kvalitatív vizsgálat mutatott rá arra, hogy 2011 után a kerületben a lakosság átlagos társadalmi-gazdasági státusának változása mellett annak sokszínúsége is erősödött. A kutatás alapján Jacquier et al. (2007) továbbfejlesztett modelljével modellezhetôvé vált a különböző városrehabilitációs stratégiák eltérő társadalmi hatása (7. ábra).

A városrészek rehabilitációs stratégiái és a társadalmi hatások, Józsefváros példáján

Urban renewal strategies of city quarters and the social effects, on the example of Józsefváros

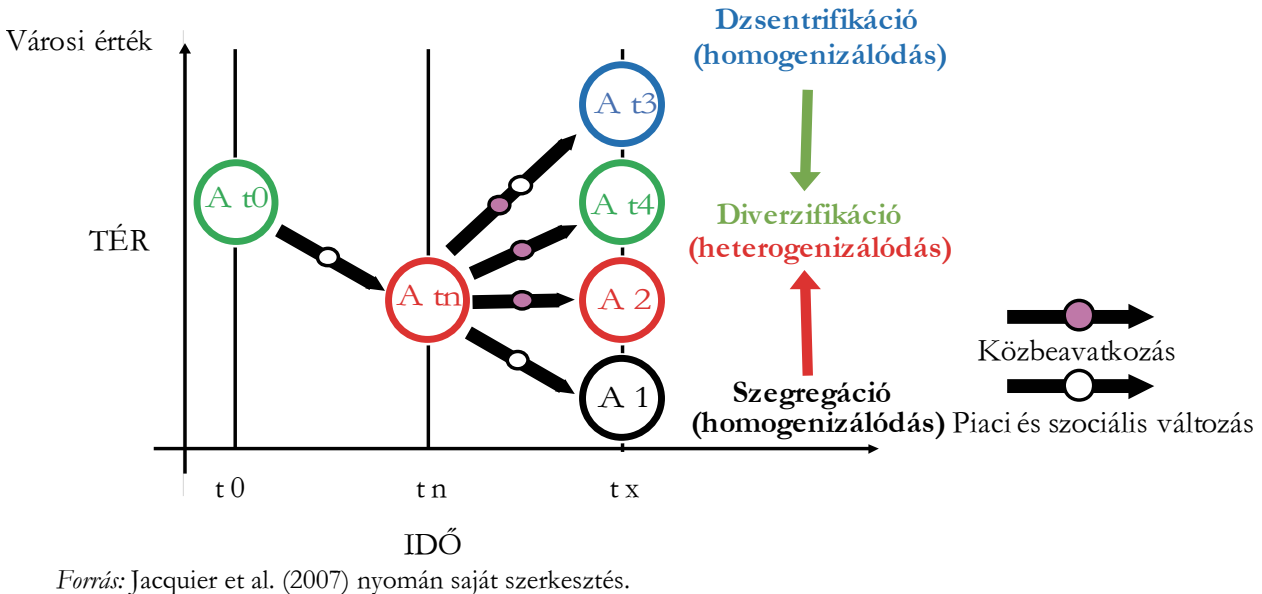

A városrehabilitációval nem érintett városrészek esetében a társadalmi-gazdasági státus további romlása volt kimutatható (például Orczy negyed, az ábrán: A1). A szociálisan érzékeny, a lakásállománynak csak alapszintű korszerűsítését előtérbe helyező, kisléptékű városrehabilitáción (például Magdolna Negyed Program I. üteme, az ábrán: A2) átesett Magdolna negyed esetében a beavatkozásokkal csak a városrész további leszakadását sikerült elkerülni. Az ingatlanfejlesztési orientáltságú és

Területi Statisztika, 2019, 59(6): 606-643; DOI: 10.15196/TS590602 
ezáltal a lakásállomány radikális átalakításával járó városrehabilitációval érintett városrészek (például Corvin negyed, az ábrán: A3) esetében a lakosság általános társadalmi-gazdasági felemelkedését a városmegújitás tovább fokozta.

A Magdolna negyed szociális városrehabilitációja további, már az épített környezet komplex megújításával járó, de közvetlen lakosságcserét nem jelentő ütemei (az ábrán: A4) érték el azt a hatást, mellyel a helyi társadalom sokszínűsége elérte a kívánatos (fenntartható) szintet.

Vizsgálatom alapján megállapítható volt, hogy a városrehabilitáció erőteljes hatást gyakorol a társadalmi sokszínúségre. Általában a városrehabilitáció kezdeti szakaszában erősíti egy városrész sokszínúségét, hosszú távon azonban a homogenizációt. A társadalmi sokszínúség változása legkevésbé a társadalmi mobilitásra, leginkább a társadalmi kohézióra és a gazdasági teljesítményre hat. Előbbire negatív, utóbbira pozitív előjellel.

A diverzitáskutatás rámutatott arra, hogy érdemes figyelembe venni a városrehabilitáció gyakorlatának sokszínúségét, a különböző típusú városrehabilitációs beavatkozások társadalmi sokszínűségre gyakorolt eltérő hatásait. A kutatás egyik fontos eredménye, hogy a városrehabilitáció negatív társadalmi hatásainak (például gyengülő kohézió) ellensúlyozása miatt a beavatkozások szerves részének kell tekinteni a társadalmi, szociális és közösségfejlesztési eszközöket, melyek hozzájárulhatnak a társadalmi kohézióhoz erősödéséhez. A helyi társadalom megerősítése, a sokszínűség megőrzése és erősítése érdekében javasolt különböző szereplők bevonása a városrehabilitációs programok végrehajtásába, a nyilvánosság biztosítása, szervezési technikák, közösségi tervezési módszerek, társadalmi programok és közösségi akciók által (Horváth et al. 2018).

További kutatások tárgyát képezheti, hogy a komplex városrehabilitációs programok különböző beavatkozásai mely célcsoportok eléréséhez kínálnak hatékony eszközöket, és ezek a különböző beruházási és nem beruházási tevékenységek miként befolyásolják a társadalmi sokszínúséget.

Napjaink jelentős józsefvárosi városrehabilitációs programjai 10-15 éve zajlanak, egyes programok a befejezésükhöz közelednek, emiatt a jövőben szintén érdemes lesz vizsgálni a szervezett városmegúííást követő időszak spontán társadalmigazdasági folyamatait és annak hatásait a társadalmi sokszínúségre. Vajon a különböző eszközökkel megújított, felzárkóztatott negyedek társadalmi-gazdasági „,visszasüllyedése", vagy tartós dzsentrifikálódása következik-e be, esetleg fenntartható-e egy „arany középút”. Ez esetben Józsefváros a jövőben is egyaránt lakóhelye lehet a Palotanegyed régi vagy a Corvin negyed új tehetôs társadalmi csoportjai, valamint a kerület középső részén fekvő lakónegyedek méltányos lakáskörülmények között élő, alacsonyabb státusú lakosai számára.

Területi Statisztika, 2019, 59(6): 606-643; DOI: 10.15196/TS590602 


\section{IRODALOM}

ALFÖLDI, GY. (2007) Épitész szerepek a városfejlesztésben: Budapest - Józsefváros, Futó utca megúizitása. DLA Értekezés, Budapesti Műszaki és Gazdaságtudományi Egyetem Építészmérnöki Kar, Budapest.

AlFÖLDI, GY.-CZEGLÉDY, Á.-HoRvÁTH, D. (2007) Egy ébredő városrész - részvételi típusú városmegújítás a Józsefvárosban. In: KONDOR, A. Cs.-EGEDY T. (szerk.): Városfejlódés és városrehabilitáció: budapesti és lipcsei tapasztalatok pp. 101-110., Magyar Földrajzi Társaság, Budapest.

ALFÖLDI, GY.-HoRvÁTH, D. (2009) Hogyan tovább? Egy részvételi folyamat fenntarthatóságának kérdései: Tapasztalatok Budapest-Józsefvárosból Földrajzi Közlemények 133 (4): 510-515.

BALIzS, D.-BAJMÓCY, P. (2013) Kvantitatív etnikai földrajzi vizsgálatok a történeti Vas megye példáján Területi Statisz̨tika 53 (5): 457-474.

Barta, G.-Beluszky, P.-CZIrfusz, M.-Győri, R.-Kukely, GY. (2006): Rehabilitating the Brownfield Zones of Budapest Centre for Regional Studies, Hungarian Academy of Sciences. Discussion Papers 51. Pécs.

Barrosio, M.-Eynard, E.-Marietta, C.-Marra, G.-Melis, G.-Tabasso, M. (2016): From urban renewal to urban regeneration: Classification criteria for urban interventions. Turin 1995-2015: Evolution of planning tools and approaches Journal of Urban Regeneration and Renewal 9 (4): 367-380.

Beluszky, P.-Timar, J. (1992): The changing political system and urban restructuring in Hungary Tijdschrift voor Economische en Sociale Geografie 83 (5): 380-389. https://doi.org/10.1111/j.1467-9663.1992.tb00618.x

BELuSZKY, P. (1992): Csanádi Gábor-Ladányi János: Budapest térbeni-társadalmi szerkezetének változásai Tér és Társadalom 6 (3-4): 289-290. https://doi.org/10.17649/TET.6.3-4.2925

BERÉNYI, B. E. (2010) Történelmi városrészek átalakulásának társadalomföldrajzi vizsgálata Budapest belvárosában Doktori értekezés, p. 125., ELTE TTK, Budapest.

BERKI, M. (2014) Visszatérés a kapitalizmus útjára: a posz̨tszocialista városfejlódés föbb jellemæöinek áttekintése (kézirat) Eötvös Loránd Tudományegyetem, Regionális Tudományi Tanszék, Budapest.

BEynOn, E. D. (1943): Budapest: An Ecological Study. Geographical Review 33 (2): 256-275. https://doi.org/10.2307/209777

Bolt, G.-VAN Kempen, R. (2013) Neighbourhood based policies in the Netherlands: counteracting neighbourhood effects? In: MANLEY, D.-VAN HAM, M.-BAILEY, N.-SimpsOn, L.-MACLENNAN, D. (eds.): Neighbourbood Effects or Neighbourbood Based Problems? pp. 195-213., Springer, Dordrecht. https://doi.org/10.1007/978-94-007-6695-2_10

BOND, L.-SAUTKINA, E.-KEARNS, A. (2011): Mixed messages about mixed tenure: do reviews tell the real story? Housing Studies 26 (1): 69-94. https://doi.org/10.1080/02673037.2010.512752

Boros, L.-FABULA, SZ. (2017): A sokszínűség érzékelése és megítélése Józsefvárosban REGIO 25 (4): 80-107.

Területi Statisztika, 2019, 59(6): 606-643; DOI: 10.15196/TS590602 
Boros, L.-Fabula, Sz.-Horváth, D.-Kovács, Z. (2016): Urban diversity and the production of public space in Budapest Hungarian Geographical Bulletin 65 (3): 209-224. https://doi.org/10.15201/hungeobull.65.3.1

BRÄNNSTRÖM, L.-ROJAS, Y. (2012): Rethinking the long-term consequences of growing up in a disadvantaged neighbourhood: lessons from Sweden Housing Studies 27 (6): 729-747. https://doi.org/10.1080/02673037.2012.714460

CsanÁd, G.-Csizmady, A.-Kocsis, J. B.-KÖszeghy, L.-Tomay, K. (2010) Város Tervezó Társadalom Sík Kiadó, Budapest.

Csanádi, G.-Csizmady, A. (2002) Szuburbanizáció és társadalom Tér és Társadalom 16 (3): 27-55. https://doi.org/10.17649/TET.16.3.1978

CSANÁDI, G.-LADÁNYI, J. (1987) Budapest: a városszerkę̧et történetének és a különbözőó társadalmi csoportok városszerkezeti elhelyezkedésének vizsgálata Kandidátusi értekezés, Budapest.

Csizmady, A. (2011) Városrehabilitáció és sebezhetőség. In: Tamás P.-Bulla M. (szerk.): Sebezhetôség és adaptáció: a reziliencia esélyei pp. 115-131., MTA Szociológiai Kutatóintézet, Budapest,

CZAIKA, M.-DE HAAS, H. (2014): The globalization of migration: Has the world become more migratory? International Migration Review 48 (2): 283-323. https://doi.org/10.1111/imre.12095

Deumert, A. (2014): Digital superdiversity: A commentary. Discourse, Context \& Media 2 (4-5): 116-120. https://doi.org/10.1016/j.dcm.2014.08.003

DÖVÉNYI, Z.-NÉMETH, Á. (2014): A vallási sokszínűség változása Magyarországon 2001 és 2011 között Területi Statisұtika 54 (6): 550-573.

Duncan, O. D.-DunCAN, B. (1955): A methodological analysis of segregation indexes American Sociological Review 20 (2): 210-217. https://doi.org/10.2307/2088328

EGEDY, T. (2007) A történelmi belvárosok rehabilitációja vidéki nagyvárosainkban - Szeged és Győr In: ENYEDI, GY. (szerk.): A történelmi városközpontok átalakulásának társadalmi hatásai - Magyarország az ęredfordulón pp. 261-292., Stratégiai tanulmányok a Magyar Tudományos Akadémián - Múhelytanulmányok, MTA Társadalomkutató Központ, Budapest.

EGEDY, T. (2008): A városrehabilitáció lehetséges hatásai a helyi társadalomra és az életminőségre - Esettanulmány a középső-józsefvárosi Mátyás tér felújításának várható hatásairól In: CSANÁDI, G.-CSIZMADY, A.: Társadalom - Tér - Szerkezet pp. 231258., ELTE TáTK, Városi és Regionális Kutatások Központja, Budapest.

EGEDy, T.-KovÁcs, Z. (2005): A városrehabilitáció néhány elméleti kérdése In: EGEDY, T. (szerk): Városrehabilitáció és társadalom pp. 9-20., MTA FKI, Budapest.

Egedy, T.-KovÁcs, Z.-Kondor, A. Cs. (2017): Metropolitan region building and territorial development in Budapest: the role of national policies International Planning Studies 22 (1): 14-29. https:/ / doi.org/10.1080/13563475.2016.1219652

FAbula, SZ.-Boros, L.-HorvátH, D.-KovÁcs, Z. (2017): DIVERCITIES: dealing with urban diversity: the case of Budapest, Utrecht University, Utrecht.

FAbula, SZ.-Boros, L.-KovÁcs, Z.-HorvátH, D.-PÁL, V. (2017): Studentification, diversity and social cohesion in post-socialist Budapest Hungarian Geographical Bulletin 66 (2): 157-173. https://doi.org/10.15201/hungeobull.66.2.5

FAIST, T. (2009): Diversity: a new mode of incorporation? Ethnic and Racial Studies 32 (1): 171-190. https://doi.org/10.1080/01419870802483650

Területi Statisztika, 2019, 59(6): 606-643; DOI: 10.15196/TS590602 
FÖLDI, Zs. (2006): Neighbourhood Dynamics in Inner-Budapest: A Realist Approach Netherlands Geographical Studies 350 Faculteit Geowetenschappen Universiteit, Utrecht.

FÖLDI, Zs.-VAN WEESEP, J. (2007): Impacts of globalisation at the neighbourhood level Journal of Housing and the Built Environment 22 (1): 33-50. https://doi.org/10.1007/s10901-006-9065-2

Galster, G.-Andersson, R.-Musterd, S.-Kauppinen, T. M. (2008): Does neighbourhood income mix affect earnings of adults? New evidence from Sweden Journal of Urban Economics 63 (3): 858-870. https://doi.org/10.1016/j.jue.2007.07.002

Gentile, M.-TAmmaru, T.-VAn Kempen, R. (2012): Heteropolitanization. Social and Spatial Change in Central and East European Cities (Guest Editorial) Cities (29): 291-299. https://doi.org/10.1016/j.cities.2012.05.005

GORDOn, I.-MONASTIRIOTIS, V. (2006): Urban size, spatial segregation and inequality in educational outcomes Urban Studies 43 (1): 213-236. https://doi.org/10.1080/00420980500409367

Hegedüs, J.-Tosics, I. (1994): Privatisation and rehabilitation in the Budapest inner districts Housing Studies 9 (1): 39-54. https://doi.org/10.1080/02673039408720774

HeGEDÜs, J.-Tosics, I. (1991) 'Gentrification in Eastern Europe: The case of Budapest'. In: VAN WEeSEP, J.-MUSTERD, S. (eds): Urban Housing for the Better-Off: Gentrification in Europe' pp. 124-136., Stedelijke Netwerken, Utrecht.

Horváth, D.-Keresztes-Sipos, A.-LukÁcsházi, G.-Avar, Z.-ViráG, D. B.-HÁmori, P. (2018): Navigátor - Kézikeönyv a társadalmi bevonáshoz Budapest Főváros Önkormányzata Főpolgármesteri Hivatala, Budapest.

HorváTH, D. (2009): Egy új városrehabilitációs gyakorlat első tapasztalatai Falu-Város-Régió $11(2): 81-83$.

HorvÁTH, D.-TELLER, N. (2008): Egy városmegújítási modell tapasztalatai In: ALFÖLDI, GY.-KovÁcs, Z. (szerk.): Városi Zöld Könyv - kulcs a fenntartható városhoz pp. 5157., Építésügyi Tájékoztató Központ-MTA FKI-Rév8 Zrt, Budapest.

JACQUIER, C.-BIENVENUE, S.-SCHLAPPA, H. (2007): Urban regeneration of deprived areas across Europe Final report. REGENERA, Lyon.

KÄHRIK, A.-TAMMARU, T. (2010): Soviet prefabricated panel housing estates: Areas of continued social mix or decline? The case of Tallinn Housing Studies 25 (2): 201-219. https://doi.org/10.1080/02673030903561818

KOK, H.-KovÁcs, Z. (1999): The process of suburbanization in the agglomeration of Budapest Netherlands Journal of Housing and the Built Environment 14 (2): 119-141. https://doi.org/10.1007/BF02496818

Kohlbacher, J.-Protasiewicz, P. M. (2012): The Ethnic Economy in CEE Metropolises: A Comparison of Budapest, Prague, Tallinn and Wroclaw CMR Working Papers 59/117., University of Warsaw.

KOMLÓSI, É.-PÁGER, B. (2015): The impact of urban concentration on countries' competitiveness and entrepreneurial performance Regional Statistics 5 (1): 97-120. https://doi.org/10.15196/RS05106

Területi Statisztika, 2019, 59(6): 606-643; DOI: 10.15196/TS590602 
KoneckA-SzYdłowsKA, B.-TrócsánYI, A.-PIRISI, G. (2018): Urbanisation in a formal way? The different characteristics of the 'newest towns' in Poland and Hungary Regional Statistics 8 (2): 135-153. https://doi.org/10.15196/RS080202

KONRÁD, GY.-SZELÉNYI, I. (1971) A késleltetett városfejlődés társadalmi konfliktusai Valóság 14 (12): 19-35.

KovÁCs, Z. (2012): Residential segregation in Budapest before and after transition In: MALOUTAS, T.-FujITA, K. (eds.): Residential segregation in comparative perspective: making sense of contextual diversity pp. 197-216., Ashgate, Aldershot.

KovÁcs, Z. (2009): Social and economic transformation of historical neighbourhoods in Budapest Tijdschrift voor Economische en Sociale Geografie 100 (4): 399-416. https://doi.org/10.1111/j.1467-9663.2009.00549.x

KovÁCs, Z. (1998): Ghettoization or gentrification? Post-socialist scenarios for Budapest Netherlands Journal of Housing and the Built Environment 13 (1): 63-81. https://doi.org/10.1007/BF02496934

KovÁcs, Z.-Herfert, G. (2012): Development pathways of large housing estates in postsocialist cities: An international comparison Housing Studies 27 (3): 324-342. https://doi.org/10.1080/02673037.2012.651105

KOvÁCS, Z.-WiesSNER, R.-ZisCHNER, R. (2013): Beyond gentrification: Diversified neighbourhood upgrading in the inner city of Budapest Geografie-Sbornik Ceske Geograficke Spolecnosti 120 (2): 251-274. https://doi.org/10.1177/0042098012453856

KovÁcs Z.-SZABÓ B. (2017): A városi diverzitás jellemzői Budapesten a rendszerváltozás után REGIO 25 (4): 57-79. https://doi.org/10.17355/rkkpt.v25i4.187

KovÁCS, Z.-SZABÓ, B. (2016): Urban restructuring and changing patterns of socioeconomic segregation in Budapest In: TAMMARU, T.-MARCIŃCZAK, S.-VAN HAM, M.-MusTERD, S. (eds.). Socio-economic segregation in European capital cities: East meets West pp. 238-260., Routledge, London; New York.

LADÁNYI, J. (2002): Residential segregation among social and ethnic groups in Budapest during the post-communist transition. In: MARCuSE, P.-VAN KEMPEN, R. (eds.): Of States and Cities pp. 170-182., Oxford University Press, Oxford.

LADÁNYI, J. (1993): Patterns of residential segregation and the Gypsy minority in Budapest International Journal of Urban and Regional Research 17 (1): 30-41. https://doi.org/10.1111/j.1468-2427.1993.tb00210.x

LADÁNYI, J. (1989) Changing patterns of residential segregation in Budapest. International Journal of Urban and Regional Research 13 (4): 555-572. https://doi.org/10.1111/j.1468-2427.1989.tb00136.x

LAdos, G.-Hegedüs, G. (2019) Return migration and identity change: A Hungarian case study Regional Statistics 9 (1): 150-167. https://doi.org/10.15196/RS090109

LeETMAa, K.-TAmmaru, T.-AnNisTe, K. (2009): From priorities-to market-led suburbanisation in a post-communist metropolis Tijdschrift voor Economische en Sociale Geografie 100 (4): 436-453. https://doi.org/10.1111/j.1467-9663.2009.00551.x

Lichtenberger, E.-CsÉFAlvay, Z.-PAAL, M. (1995): Az átmenet trendjei 2. - Várospusz̨ulás és városfelújitás Budapesten Magyar Trendkutató Központ, Budapest.

MAKONI, S. (2012): A critique of language, languaging and supervernacular Muitas Vozes 1 (2): 189-199. https://doi.org/10.5212/MuitasVozes.v.1i2.0003

Területi Statisztika, 2019, 59(6): 606-643; DOI: 10.15196/TS590602 
Marcińczak, S.-TAmmaru, T.-Novák, J.-Gentile, M.-Kovács, Z.-Temelová, J.VALATKA, V.-KÄHRIK, A.-SZABÓ, B. (2015): Patterns of socioeconomic segregation in the capital cities of fast-track reforming postsocialist countries Annals of the Association of American Geographers 105 (1): 183-202. https://doi.org/10.1080/00045608.2014.968977

MARCińCZAK, S.-GENTILE, M.-STEPNiAK, M. (2013): Paradoxes of (post)socialist segregation: Metropolitan sociospatial divisions under socialism and after in Poland Urban Geography 34 (3): 327-352. http://dx.doi.org/10.1080/02723638.2013.778667

MARCIŃCZAK, S.-MUSTERD, S.-STEPNIAK, M. (2012): Where the grass is greener: Social segregation in three major Polish cities at the beginning of the 21 st century European Urban and Regional Studies 19 (4): 383-403. http://dx.doi.org/10.1177/0969776411428496

Molotch, H. (1976): The city as a growth machine: Toward a political economy of place American Journal of Sociology 82 (2): 309-332. https://doi.org/10.1086/226311

Morgan, B. S. (1980): Occupational segregation in metropolitan areas in the United States, 1970 Urban Studies 17 (1): 63-69. https://doi.org/10.1080/00420988020080071

NATHAN, M. (2011): The long-term impacts of migration in British cities: diversity, wages, employment and prices. SERC Discussion Papers. Spatial Economics Research Centre (SERC), London School of Economics and Political Sciences, London.

NÉmETH, Á. (2016): Diversity studies: új társadalomtudományi paradigma? REGIO 24 (2): 203-218. http://dx.doi.org/10.17355/rkkpt.v24i2.119

Nemes Nagy, J. (1998) A tér a társadalomkutatásban Hilscher Rezső Szociálpolitikai Egyesület, Budapest.

ProbÁLD, F. (1975): A study of residential segregation in Budapest Annales Universitatis Scientiarium Budapestinensis de Rolando Eötvös Nominatae - Sectio Geographica, pp. 103112.

RoBerTs, P.-SyKes, H. (2000): Urban regeneration - A Handbook SAGE Publications, London.

SAILER-FliEgE, U. (1999): Characteristics of post-socialist urban transformation in East Central Europe GeoJournal 49 (1): 7-16. https://doi.org/10.1023/a:1006905405818

SÁRKÁNY, Cs.-AlFÖLDI, GY.-IFJ. ERDŐSI, S.-KOLOSSA, J.-HORVÁTH, D. (2005): Józsefváros 15 kerületfejlesztési stratégiája Rév8 Zrt., Budapest.

SASSEN, S. (1991): The global city: New York, London, Tokyo Princeton University Press, Princeton. https://doi.org/10.7440/res10.2001.14

SEPUlVEDA, L.-SYRETT, S. (2007): Out of the shadows? Formalisation approaches to informal economic activity Policy and Politics 35 (1): 87-104. https://doi.org/10.1332/030557307779657739

Smith, N. (2002): New globalism, new urbanism: Gentrification as global urban strategy Antipode 34 (3): 427-450. https://doi.org/10.1111/1467-8330.00249

SMITH, N. (2011): Új globalizmus, új urbanizmus: a dzsentrifikáció mint globális városi stratégia Fordulat (13): 28-53. https://doi.org/10.1111/1467-8330.00249

Területi Statisztika, 2019, 59(6): 606-643; DOI: 10.15196/TS590602 
Smith, A.-Stenning, A.-RochovskA, A.-Swiatek, D. (2008): The emergence of a working poor: Labor markets, neoliberalisation and diverse economies in postsocialist cities Antipode 40 (2): 283-311. https://doi.org/10.1111/j.14678330.2008.00592.x

SMITH, A.-TimÁR, J. (2010): Uneven transformations: Space, economy and society 20 years after the collapse of state socialism European Urban and Regional Studies 17 (2): 115-125. https://doi.org/10.1177/0969776409358245

STANDL, H.-KRUPICKAITE, D. (2004): Gentrification in Vilnius (Lithuania): the example of Uzupis. Europa Regiona, 12 (1): 42-51

SÝKORA, L. (2009): Post-socialist cities. In: KITCHIN, R.-THRIFT, N. (eds.) International Encyclopedia of Human Geography pp. 387-395., Elsevier, Oxford. https://doi.org/10.1016/B978-008044910-4.01072-5

SÝKORA, L.-BOUZAROVSKI, S. (2012): Multiple transformations: Conceptualising the postcommunist urban transition Urban Studies 49 (1): 43-60. https://doi.org/10.1177/0042098010397402

SzABÓ, T. (2007): Krízisterületek, szociális városrehabilitáció - modellkísérletek Budapesten. In: Kondor, A. Cs.-EGEDy, T. (szerk.): Városfejlódés és városrehabilitáció: budapesti és lipcsei tapasztalatok pp. 87-100., Magyar Földrajzi Társaság, Budapest.

SzAmuely, L. (2004): A „haldokló” jóléti állam az 1990-es években Közgazdasági Szemle 60 (10): 948-969.

SZELÉNYI, I. (szerk.) (1973): Városszociológia Közgazdasági és Jogi Könyvkiadó, Budapest.

SZIRMAI, V. (2012): Urban sprawl in Europe Regional Statistics 2 (1): 129-148. https://doi.org/10.15196/RS02109

TASAN-KoK, T.-VAn Kempen, R.-RACO, M.-BOLT, G. (2013): Towards Hyper-Diversified European Cities: A Critical Literature Review Utrecht University, Utrecht.

Timár, J.-NAGY, E. (2007): A középvárosi dzsentrifikáció és társadalmi hatásai a posztszocialista Magyarországon. In: ENYEDI, GY. (szerk.): A történelmi városközpontok átalakulásának társadalmi hatásai. Magyarország az ezredfordulón pp. 293-317., Stratégiai tanulmányok a Magyar Tudományos Akadémián. Múhelytanulmányok, MTA Társadalomkutató Központ, Budapest.

TIMÁR, J.-VÁRADI, M. M. (2001): The uneven development of suburbanization during transition in Hungary European Urban and Regional Studies 8 (4): 349-360. https://doi.org/10.1177/096977640100800407

Tosics, I. (2009): Dilemmas of Integrated Area-Based Urban Renewal Programmes The URBACT Tribune, Brussels.

Tosics, I. (2006): Spatial restructuring in post-socialist Budapest In: TsenkovA, S.Nedovic-Budic, Z. (eds): The Urban Mosaic of Post-Socialist Europe: Space, Institutions and Policy pp. 131-150., Physica-Verlag, Heidelberg.

Tosics, I. (2005): “The post-socialist Budapest: the invasion of market forces and the attempts of public leadership" In: Hamilton, F. E. I.-DimitrowsKA-ANDrEws, K.-Pichler-Milanovic, N. (eds.) Transformation of Cities in Central and Eastern Europe: Towards Globalization pp. 248-280., United Nations University Press, Tokyo.

TuroK, I. (1987): Continuity, change and contradiction in urban policy. In: DONNISON, D.Middleton, A. (eds.): Regenerating the Inner City Routledge\&Kegan Paul, London.

Területi Statisztika, 2019, 59(6): 606-643; DOI: 10.15196/TS590602 
URBAN, S. (2009): Is the neighbourhood effect an economic or an immigrant issue? A study of the importance of the childhood neighbourhood for future integration into the labour market Urban Studies 46 (3): 583-603.

https://doi.org/10.1177/0042098008100996

VAN KEMPEN, R.-BOLT, G. (2009): Social cohesion, social mix, and urban policies in the Netherlands Journal of Housing and the Built Environment 24 (4): 457-475. https://doi.org/10.1007/s10901-009-9161-1

VERTOVEC, S. (2007) Super-diversity and its implications Ethnic and Racial Studies 30 (6): 1024 1054. https://doi.org/10.1080/01419870701599465

\section{INTERNETES HIVATKOZÁSOK}

International Standard Classification of Occupations (2019). https://www.ilo.org/public/english/bureau/stat/isco/

Nemzeti Foglalkoztatási Szolgálat településsoros adatai (é. n.). https://nfsz.munka.hu/Lapok/full_afsz_kozos_statisztika/full_afsz_telepulesso ros_munkanelkulisegi_adatok.aspx

OTP (2018): Ingatlan Értéktérkép 2018/1 OTP Jelzálogbank Nyrt. https://www.otpbank.hu/OTP_JZB/file/Lakoingatlan_Ertekterkep_2018_1.pdf (letöltve: 2019.03.31.)

Vertovec, S. (2005): Opinion: Super-diversity revealed. BBC. http://news.bbc.co.uk/2/hi/uk_news/4266102.stm

Területi Statisztika, 2019, 59(6): 606-643; DOI: 10.15196/TS590602 